\title{
Invited Review: Treatment of Cows with an Extended Postpartum Anestrous Interval
}

\author{
F. M. Rhodes,${ }^{\star 1}$ S. McDougall, $†$ C. R. Burke, $\neq$ G. A. Verkerk ${ }^{\star}$, and K. L. Macmillan§ \\ ${ }^{*}$ Dexcel Limited, Private Bag 3221, Hamilton, New Zealand \\ †Animal Health Centre, PO Box 21, Morrinsville, New Zealand \\ ¥Department of Animal Science, The Ohio State University, Columbus 43210, USA \\ §University of Melbourne, Veterinary Clinical Centre, 250 Princes Highway, Werribee, Victoria 3030, Australia
}

\section{ABSTRACT}

Cows with an extended interval from calving to first ovulation (PPI) have increased intervals from calving to conception and are more likely to be culled compared with cows with a short PPI. In year-round calving dairy herds, between 11 and $38 \%$ of cows are reported as anestrus by 50 or $60 \mathrm{~d}$ after calving. In seasonally calving dairy herds, between 13 and $48 \%$ of cows are diagnosed as anovulatory anestrus at the start of the breeding period. Ovulation and estrus after calving are delayed when the positive feedback effects of estradiol on release of LH from the pituitary, and circulating concentrations of metabolic hormones such as insulin and insulin-like growth factor-I, are reduced by a variety of environmental factors. The main factors are limited energy intake, lower body reserves, increased partitioning of energy to milk production, suckling, and peripartum disease. Treatment options for cows with an extended PPI include hormonal and management strategies. Hormonal treatments that include a period of progesterone supplementation result in the majority of treated animals displaying estrus with a subsequent luteal phase of normal duration and improved pregnancy rates compared with untreated controls. Hormonal interventions also tend to have more predictable outcomes compared with management changes, such as manipulating body condition or dietary intakes after calving, and usually have some estrous synchronization effect, thus facilitating the use of artificial insemination. However, responses to any treatment are variable and are related to those factors that influence duration of the PPI, such as body condition and parity.

(Key words: cattle, postpartum, anestrus, treatment)

Abbreviation key: CIDR = controlled internal drug releasing device, $\mathbf{e C G}=$ equine chorionic gonadotropin,

Received May 13, 2002.

Accepted November 25, 2002.

Corresponding author: F. M. Rhodes; e-mail: rhodesf@wave.co.nz.
$\mathbf{E B}=$ estradiol benzoate, $\mathbf{P P I}=$ postpartum interval: calving to first ovulation.

\section{INTRODUCTION}

The early resumption of estrous cycles following calving is important for high reproductive efficiency in both year-round and seasonally calving herds. For pasturebased production systems, timing of calving is usually set to optimize the use of maximum pasture growth rate in spring and early summer. To maintain the required concentrated calving pattern, high submission rates during the early part of the breeding period are an important prerequisite. To maintain a 365-d calving interval, cows need to conceive on average by $83 \mathrm{~d}$ after calving (assuming gestation length of $282 \mathrm{~d}$ ). Delays in the commencement of ovulation and expression of estrus are associated with reduced conception rates and pregnancy rates and increased intervals from calving to conception. This is a result of fertility following insemination being greater in cows that have displayed estrus once or more before the start of breeding compared with cows inseminated at their first estrus (Thatcher and Wilcox, 1973; Macmillan and Clayton, 1980; Darwash et al., 1997b). Moreover, cows that have not been observed in estrus during the first $60 \mathrm{~d}$ after calving have a significantly higher risk of being culled than cows that have displayed estrus (Opsomer et al., $2000 \mathrm{~b})$. In both average and high yielding dairy cows, there is an economic benefit in reducing the numbers of animals with an extended interval from calving to conception (Esslemont et al., 2001).

In dairy herds with seasonal breeding systems, cows not detected in estrus by a specific calendar date, which is nominated as the start of the breeding period, are defined as anestrus. These animals may have delayed ovulation (anovulatory anestrus) or have ovulated without being detected in estrus, or have calved late and not had sufficient time to resume estrous cycles postpartum. Herds with extended calving patterns may have a large proportion of anestrous cows at the start of the 
breeding period, simply due to a high proportion of late calving cows. In practical terms, all cows not having displayed estrus at the start of the breeding period need to be examined and treated, irrespective of calving date, in order to maintain the seasonal calving pattern. Anovulatory anestrous cows have a lesser percentage of animals detected in estrus in the first $3 \mathrm{wk}$ of the breeding period (55 vs. 96\%) and longer intervals to conception ( 37 vs. $22 \mathrm{~d}$ ) than cows that have displayed estrus by the start of the breeding period (Macmillan, 2002). Between 10 and $30 \%$ of cows that have not been detected in estrus by the start of the breeding period have a detectable corpus luteum at veterinary examination. These cows have reduced pregnancy rates in the first $28 \mathrm{~d}$ of the breeding period (59 vs. $67 \%$ ) and have greater nonpregnancy rates at the end of the breeding period (10 vs. $4 \%$ ) compared with cows that have been detected in estrus (McDougall and Rhodes, 1999).

The aim of this review is to briefly summarize the physiological events and main factors influencing the duration of the postpartum anestrous interval (PPI) in cattle and then to describe some of the treatment options for cows experiencing a prolonged PPI.

\section{THE POSTPARTUM ANESTROUS PERIOD}

Following calving, the reproductive strategy of the cow is transformed from delivering and nourishing a healthy calf to reestablishing pregnancy. The dormancy of ovarian follicular development that prevailed during late pregnancy must now be replaced by a sequence of events culminating with behavioral estrus, ovulation of healthy follicles and normal luteal function. These are the requirements for successful reproductive performance in any type of cattle production system.

\section{Establishment of the First Ovulation Postpartum}

A period of anovulatory anestrus of varying duration is observed in both milked and suckled cows following parturition. In milked dairy cattle the interval from calving to first ovulation is typically between 19 and 22 d (Fonseca et al., 1983; Stevenson and Call, 1983; Darwash et al., 1997b). Under pasture-based management systems the mean interval is $43 \mathrm{~d}$ (McDougall et al., 1995a) and in suckled cows it can vary between 20 and $86 \mathrm{~d}$ (Lamming et al., 1981; Murphy et al., 1990). In pasture-based dairy herds, between 13 and $48 \%$ of cows were diagnosed as anovulatory anestrus $1 \mathrm{wk}$ before the start of the breeding period (Rhodes et al., 2001a). In suckled beef herds, an average of $23 \%$ of cows had not ovulated by the start of breeding, with the percentage increasing by 6 percentage units for each 10-d decrease in interval from calving (Lamb et al., 2001). Dairy cows in continuous calving systems that have not ovulated by $44 \mathrm{~d}$ postpartum have been defined as having a prolonged PPI (Lamming and Darwash, 1998). The proportion of British cows with a prolonged PPI was similar in studies conducted between 1975 and 1982 (11\%) and between 1995 and 1998 (13\%; Royal et al., 2000). These animals had a reduced firstservice conception rate and an increased number of services per conception compared with animals ovulating before $44 \mathrm{~d}$ after calving (Lamming and Darwash, 1998). Among North American dairy herds, the percentage of cows being classified as anestrus at $60 \mathrm{~d}$ or more after calving was 23\% (Moreira et al., 2001) and 38\% (Lucy, 2001), and in a study of Belgian dairy cows between 1990 and 1994, mean interval to first ovulation was $37 \mathrm{~d}$, with $22 \%$ of cows not ovulating until more than $50 \mathrm{~d}$ after calving (Opsomer et al., 2000a). Thus, there is strong evidence that the problem of extended PPI is not just limited to pasture-based management systems, but is also recognized in more intensively managed dairy cows.

Concentrations of gonadotropins are very low in late pregnancy due to strong negative feedback from progesterone and estrogens. After calving, concentrations of FSH increase within 5 to $10 \mathrm{~d}$ in both milked and suckled cows, whereas circulating concentrations of LH generally start to increase between 10 to $20 \mathrm{~d}$ postpartum. Pulsatile episodes of $\mathrm{LH}$ release are first detected around this time in milked cows, but are delayed in suckled cows, with frequency of pulses of LH release being correlated with the interval to first ovulation (Lamming et al., 1981; Beam and Butler, 1997; Crowe et al., 1998).

The growth and development of ovarian follicles, which can be detected using ultrasonography, commences within 1 or $2 \mathrm{~d}$ of the first significant increase in plasma concentrations of FSH after calving (Beam and Butler, 1997; Crowe et al., 1998). A single large, or dominant, ovarian follicle commences growth around 10 to $14 \mathrm{~d}$ postpartum in both milked and suckled cows (Murphy et al., 1990; Savio et al., 1990; McDougall et al., 1995a). This first dominant follicle may fully mature and ovulate, or become atretic and be replaced by one or more subsequent dominant follicles, or may continue growth and become cystic. Ovulation of a dominant follicle occurs when production of estradiol by the follicle is sufficient to stimulate a preovulatory surge of $\mathrm{LH}$ and FSH. Estradiol production is in turn dependent on sufficient gonadotropin support in terms of LH pulse frequency and increased plasma concentrations of estradiol are associated with elevated plasma concentrations of IGF-I (Lamming et al., 1981; Stagg et al., 1998; Beam and Butler, 1999). Both IGF-I and insulin are potent stimulators of steroidogenesis and proliferation 
of bovine granulosa and theca cells in vitro, acting synergistically with FSH or LH, as reviewed by Webb et al. (1999a) and Lucy et al. (1999).

\section{Establishment of the First Normal-Length Luteal Phase}

The first postpartum ovulation is frequently associated with an absence of estrous behavior and is often followed by a luteal phase of short duration (Webb et al., 1980; Murphy et al., 1990; McDougall et al., 1995a). The short luteal phase following the first postpartum ovulation is a consequence of interactions between the uterus, the corpus luteum, and possibly the ovulatory follicle. Premature release of $\mathrm{PGF}_{2 \alpha}$ by the uterus, rather than inadequate luteal development, is the main cause of the shortened life span of the first corpus luteum (Copelin et al., 1987; Zollers et al., 1989; Cooper et al., 1991). Low or negligible concentrations of progesterone preceding the first postpartum ovulation result in lower numbers of progesterone receptors and greater numbers of oxytocin receptors in endometrial cells, allowing early development of the positive feedback loop between oxytocin and $\mathrm{PGF}_{2 \alpha}$ (Zollers et al., 1993). Low preovulatory concentrations of estradiol are also probably involved in increasing the numbers of endometrial oxytocin receptors, thus allowing binding of oxytocin and premature release of luteolytic $\mathrm{PGF}_{2 \alpha}$ (Mann and Lamming, 2000).

A short period of elevated progesterone concentrations during the postpartum period, from either endogenous or exogenous sources, is important for the expression of estrus as well as subsequently normal luteal function (Henricks et al., 1972; Ramirez-Godinez et al., 1982; McDougall et al., 1992). The mechanism of action is not clear, but it appears to involve changes in estradiol receptor number in the hypothalamus and increases in estradiol production. Treatment of anestrous cows with progesterone results in greater follicular fluid and circulating concentrations of estradiol, increased pulsatile release of $\mathrm{LH}$ and increased numbers of receptors for LH in granulosa and theca cells in preovulatory follicles, compared with untreated animals (GarciaWinder et al., 1986, 1987; Inskeep et al., 1988; Rhodes et al., 2002). It is hypothesized that exposure of anestrous cows to progesterone may stimulate development and maturation of a dominant follicle by enhancing release of $\mathrm{LH}$ and stimulating development of $\mathrm{LH}$ receptors and secretion of estradiol. The increased release of $\mathrm{LH}$ is possibly due to a reduction in estradiol receptors in the hypothalamus and reduced negative feedback on release of $\mathrm{GnRH}$, as demonstrated in the prepubertal heifer (Day and Anderson, 1998).
The development of ovarian follicles and associated changes in circulating concentrations of reproductive hormones during the postpartum period are presented diagrammatically in Figure 1. To summarize, the interval from calving to first postpartum ovulation is characterized by a period of increasing pulsatile release of $\mathrm{LH}$, associated with the growth and development of ovarian follicles. In order for those follicles to mature and ovulate, gonadotropic support must be sufficient to stimulate increased production of estradiol, which can induce a preovulatory surge of LH and FSH. In addition, circulating concentrations of metabolic hormones, such as IGF-I, are involved in optimizing the response of ovarian granulosa and theca cells to gonadotropin stimulation. The luteal phase following the first postpartum ovulation is of short duration, due to premature release of $\mathrm{PGF}_{2 \alpha}$ from the uterus, associated with greater numbers of oxytocin receptors in the endometrium. This short period of elevated progesterone concentrations is required for the full expression of estrus and a luteal phase of normal duration.

\section{RISK FACTORS FOR A PROLONGED PPI}

Three categories of anovulation have been recently defined by Wiltbank et al. (2002) using ultrasonographically defined ovarian follicular growth patterns.

Anovulation with follicle growth not progressing beyond the 'emergence' stage of development may be observed in animals subject to severe nutritional restriction, especially in Bos indicus breeds of cattle. This condition results in the absence of any ovarian follicles $>8 \mathrm{~mm}$ in diameter and is associated with the virtual absence of pulsatile release of LH (Jolly et al., 1995; Rhodes et al., 1995).

Anovulation with follicle growth to less than ovulatory follicle size is observed in most cows that display a prolonged PPI and is the usual condition exhibited by postpartum suckled beef cows and dairy cows managed in pasture-based systems (Murphy et al., 1990; McDougall et al., 1995a). It is associated with a relatively low frequency of pulsatile LH release and increased sensitivity to the negative feedback effects of estradiol on gonadotropin release (Garcia-Winder et al., 1984; McDougall et al., 1998).

Anovulation with follicular growth to larger than ovulatory follicle size (follicular cysts) may be observed in lactating dairy cows, but is uncommon in beef cows. This category of anovulation covers a variety of physiological conditions and can be associated with an absence or excess of sexual behavior; it is thought to be related to increased release of $\mathrm{LH}$ with an insensitivity to estradiol positive feedback (Wiltbank et al., 2002). 


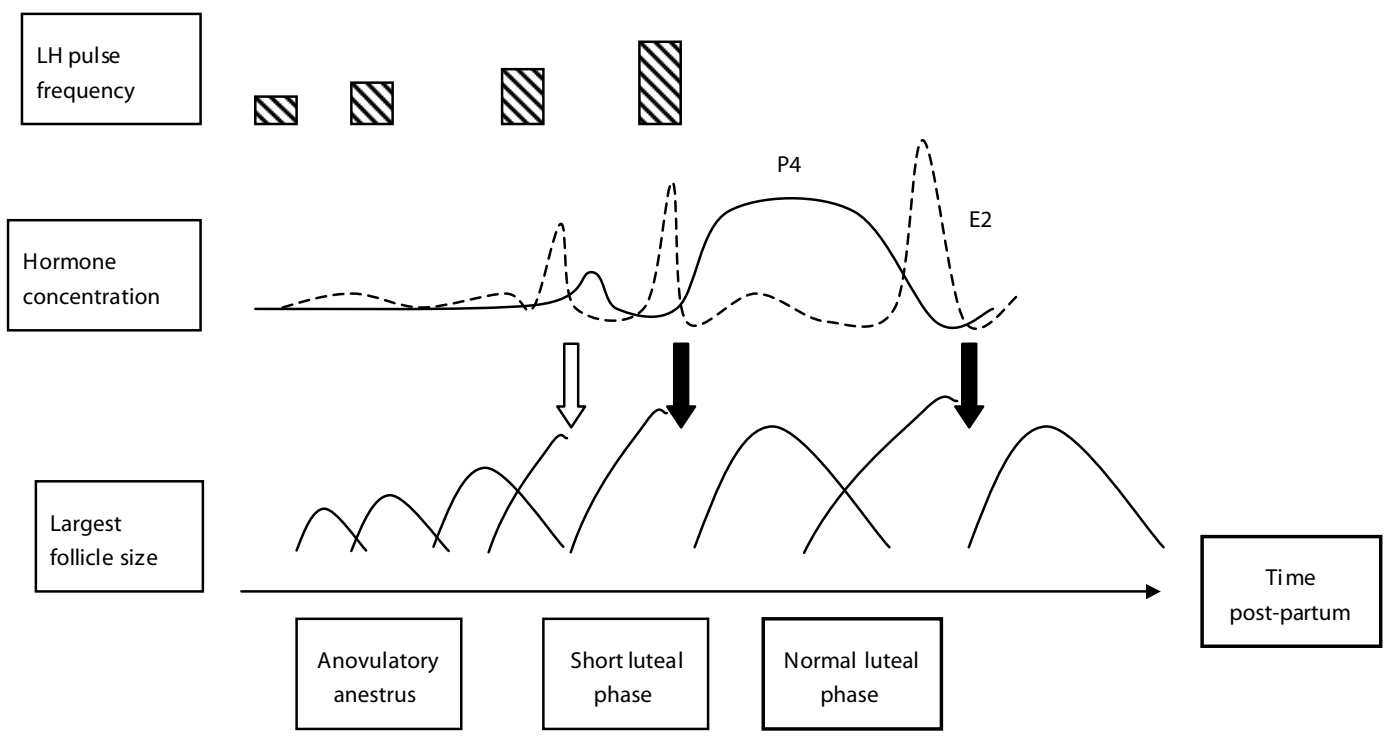

Figure 1. Schematic diagram demonstrating the development of largest ovarian follicles and associated changes in circulating concentrations of estradiol (E2), progesterone (P4) and frequency of pulsatile LH release, during the postpartum period. Ovulation without estrus is indicated by an open arrow and ovulation with expression of estrus by a solid arrow.

This review will focus on the second category of anovulation. The main factors that have been identified as influencing the duration of the PPI are nutrition before or after calving, age or parity, season and periparturient disease. In suckled cows, the maternal bond between the cow and her own calf is the major factor resulting in delayed resumption of ovulation and is dependent upon visual and/or olfactory signals between dam and calf (Williams and Griffith, 1995). Moreover, in both beef and dairy cows, the presence of the cow's own calf, despite inhibition of suckling, results in a delay in resumption of ovulation and estrous cycles (Macmillan, 1983; Williams and Griffith, 1995).

\section{Influence of Nutrition}

Body condition at calving strongly influences duration of PPI in both dairy and beef cows. In pasturefed dairy cattle, increasing body condition results in a significant decrease in the interval to first estrus or ovulation (Grainger et al., 1982; Burke et al., 1995) and in beef cattle, body condition at calving is related to the percentage of cows resuming estrous cycles before the breeding season or duration of PPI (Wiltbank et al., 1962; Wright et al., 1987; Vizcarra et al., 1998). In dairy cows in Florida, the percentage of cows classified as anestrus was also related to body condition at $63 \mathrm{~d}$ postpartum (Moreira et al., 2001).

Prepartum nutritional status appears to have a greater influence on the duration of the PPI than postpartum nutrition, such that beef cows calving in poor body condition have a prolonged PPI even when energy intakes postpartum are greater than recommended (Wiltbank et al., 1962; Wright et al., 1987; Stagg et al., 1998). Modeling of change in body condition before and after calving in pasture-based dairy cattle also suggests that the absolute condition at calving is more important than changes post-calving on duration of PPI (McDougall, 1994). However, in pasture-fed dairy cows, additional feeding during the first $5 \mathrm{wk}$ of lactation reduced the interval to first estrus and cows maintained at low stocking rates after calving had shorter periods of anestrus compared with cows at greater stocking rates (Grainger et al., 1982; McDougall et al., 1995c). Other studies using dairy cows in supplemented feeding systems have demonstrated that change in body condition after calving, rather than condition at calving has a significant effect on the percentage of dairy cows exhibiting a prolonged PPI (Opsomer et al., 2000a; Stockdale, 2001).

In dairy cows that are fed TMR, attention has focused on the relationship between the duration of PPI and the degree of negative energy balance in the postpartum period. Energy balance reflects the difference between energy consumed and that expended for maintenance and milk production. Interval to first ovulation after calving has been reported to increase with increasing negative energy balance in some studies (Butler et al., 1981; Ducker et al., 1985; Senatore et al., 1996), but have no association in others (Villa-Godoy et al., 1988; Spicer et al., 1990; Lucy et al., 1992). Alternatively, duration of PPI has been shown to be related to the 
interval to the maximum negative energy balance (the energy balance nadir; Canfield and Butler, 1990; Senatore et al., 1996; Beam and Butler, 1997).

In practice, it is not possible to measure energy balance accurately, and physiological indicators of metabolic status may better reflect the signals controlling resumption of ovulation (see Webb et al., 1999b). In cows that have been selected for increased or decreased milk yields, a significantly longer interval to first ovulation after calving was observed in animals producing more milk, which was associated with higher circulating concentrations of growth hormone and $\beta$-hydroxy butyrate, and lower concentrations of insulin and glucose (Gutierrez et al., 1999; Gong et al., 2002). Other studies have demonstrated significant relationships between PPI and the ratio of insulin to growth hormone in plasma (Beam and Butler, 1997) and circulating concentrations of IGF-I (Roberts et al., 1997). A case-control study demonstrated lower circulating concentrations of glucose and thyroxin and higher concentrations of urea in anovulatory anestrous cows, compared with contemporary cows that had resumed estrous cycles (McDougall et al., 1993). However, other studies have failed to demonstrate any relationship between duration of PPI and concentrations of blood metabolites measured during the postpartum period (Canfield and Butler, 1990; Zurek et al., 1995; Vizcarra et al., 1998). de Vries and Veerkamp (2000) investigated a number of variables derived from milk yield data in order to find an easy measure and indicator of energy balance status for lactating cows. Change in milk fat percentage during early lactation was reported to have the best predictive value for a number of measures of energy balance, including the nadir of energy balance. However, regression coefficients of interval to start of luteal activity on change in fat percentage were not significantly different from zero, indicating that other factors not related to energy balance were responsible for a delayed return to luteal activity.

\section{Influence of Season}

Season of year influences the duration of the PPI in both suckled and milked cattle. In temperate climates, animals calving before the summer solstice have significantly longer intervals to first ovulation than those calving afterwards (Lamming et al., 1981; Fonseca et al., 1983; Opsomer et al., 2000a). In subtropical environments, reproductive performance is decreased during the warm season, compared with the cool season, with interval to first ovulation being longer in summer compared with winter calving cows (Jonsson et al., 1997). Within seasonal calving systems, PPI is significantly shorter in animals calving in late compared with early spring (Montgomery et al., 1985; McDougall et al., 1995c). Changes in pasture quality and quantity are likely to account for seasonal effects on PPI.

\section{Influence of Parity}

A positive relationship between parity and duration of PPI in British dairy cows was described by Darwash et al. (1997a). A similar relationship was described in North American Holsteins by Fonseca et al. (1983), although interval to first ovulation was also reported to be longer in 2-yr old or primiparous cows compared with 3-yr old animals or multiparous cows (Fonseca et al., 1983; Lucy et al., 1992). In pasture-based dairy systems, duration of PPI is longer in primiparous animals than in older cows (Burke et al., 1995; McDougall et al., 1995c), with a significant decrease in the probability of a cow being anestrus at the start of the breeding period with increasing age (Rhodes et al., 1998b). These relationships probably reflect the greater nutritional stress being imposed on younger cows due to requirements for growth as well as lactation.

\section{Influence of Periparturient Diseases}

In studies involving North American and Belgian dairy cows, abnormal calvings or puerperal disorders such as metritis or abnormal vaginal discharge, or the occurrence of clinical diseases such as mastitis, severe lameness and especially ketosis during the first month after calving were all reported to be significant risk factors for an extended PPI (Fonseca et al., 1983; Opsomer et al., 2000a). In contrast, a New Zealand study demonstrated no effect of peripartum diseases on the prevalence of anestrus at the start of the breeding period (McDougall, 2001a).

To summarize, a prolonged PPI is observed when the increase in release of $\mathrm{LH}$ and/or metabolic signals is delayed by suckling, low energy intake, low body reserves, increased partitioning of energy to milk production, or increased stress from disease or high environmental temperatures. The pathways involved remain unknown; however, animals with a delayed interval to first ovulation exhibit a reduced sensitivity of the hypothalamus and/or pituitary to the positive feedback effects of estradiol.

\section{TREATMENTS TO REDUCE THE POSTPARTUM INTERVAL}

Treatment options for cows with an extended PPI may be categorized into management tools and hormonal interventions. The former may include nutri- 
Table 1. Reproductive outcomes from hormonal treatments (T) for anovulatory anestrous suckled beef cows with or without restricted suckling (RS) of calves. Unless otherwise stated controls $(\mathrm{C})$ were untreated.

\begin{tabular}{|c|c|c|c|c|}
\hline Reference & Protocol & $\begin{array}{l}\text { No. of cows } \\
(T, C)\end{array}$ & $\begin{array}{l}\text { Ovulated with } \\
\text { corpus luteum of } \\
\text { normal duration } \\
(\mathrm{T}, \mathrm{C})\end{array}$ & $\begin{array}{l}\text { Pregnancy rate } \\
\text { (T vs. C) }\end{array}$ \\
\hline Fike et al. (1997) & 7-d CIDR + EB ${ }^{1}$ & 93,91 & $71 \%, 16 \% \mathrm{~b}$ & \\
\hline Garcia-Winder et al. (1986) & 9-d norgestomet $+\mathrm{hCG}^{2}$ & 30,27 & $53 \%, 0 \% \mathrm{a}$ & \\
\hline Geary et al. (1998) & RS + Ovsynch vs. "Syncro-Mate"3 & 111,116 & & $49 \%, 43 \%$ by $60 \mathrm{~d}^{4}$ \\
\hline Mackey et al. (2000) & $\mathrm{RS}+6-\mathrm{d}$ CIDR & 13,13 & $69 \%, 0 \%{ }^{\mathrm{a}}$ & \\
\hline Stevenson et al. (2000) & GnRH +7 -d norgestomet $+\mathrm{PGF}_{2 \alpha}$ vs. $2 \times \mathrm{PGF}_{2 \alpha}$ & 176,170 & & $34 \%, 12 \%$ by $6 \mathrm{~d}^{4}$ a \\
\hline
\end{tabular}

asignificance of difference between $\mathrm{T}$ and $\mathrm{C}(P<0.05)$.

${ }^{\mathrm{b}}$ Significance of difference between $\mathrm{T}$ and $\mathrm{C}(P<0.001)$.

${ }^{1} \mathrm{CIDR}=$ controlled internal drug release device, $\mathrm{EB}=$ estradiol benzoate.

${ }^{2} \mathrm{hCG}=$ human chorionic gonadotropin.

${ }^{3}$ Ceva Laboratories, Inc., Overland Park, KS.

${ }^{4}$ Days after insemination.

tional supplements and reduced milking frequency (either calf removal or once daily milking of dairy cows). Hormonal interventions aim to induce ovulation and estrus by stimulating maturation of ovarian follicles, by directly or indirectly inducing a surge in release of $\mathrm{LH}$.

\section{HORMONAL TREATMENTS FOR ANOVULATORY ANESTROUS COWS}

Ovulation can be successfully induced in anestrous beef or dairy cattle simply by using $\mathrm{GnRH}$ analogues or chorionic gonadotropins. However when used in isolation, such treatments require the presence of a functional ovarian dominant follicle, they are not always associated with expression of estrus and a majority of animals return to anovulatory anestrus following treatment (Garcia-Winder et al., 1986; Crowe et al., 1993; McDougall et al., 1995b). Estradiol may also be used to induce estrus with or without concurrent ovulation (McDougall et al., 1992). With all these treatments, ovulation is usually followed by a luteal phase of short duration, but when preceded by a period of treatment with progesterone or a progestogen they are usually followed by normal length estrous cycles. Therefore, most hormonal treatments involve the use of progesterone or a progestogen. The following section describes a number of different protocols which have been evaluated in controlled trials in either anestrous suckled beef cows or milked dairy cows. Reproductive performance following a number of treatment regimens is summarized in Tables 1 and 2 .

\section{Use of Progesterone Alone}

The use of progesterone alone to stimulate the early resumption of estrous cycles in suckled or dairy cows was reported to be successful in some studies (Miksch et al., 1978; Fike et al., 1997), but not others (Saiduddin et al., 1968; Brown et al., 1972; Kyle et al., 1992). The development of controlled intravaginal progesterone releasing devices such as the PRID (progesterone-releasing intravaginal device; Sanofi Animal Health Ltd., France) and CIDR (controlled internal drug releasing device; DEC-InterAg, Hamilton, New Zealand) allowed the development of long-term hormonal treatments, which minimized the requirement for repeated handling of animals and circumvented delivery problems associated with the feeding of oral progestogens or injecting progesterone. Treatment of suckled beef cows with CIDR devices at the time of restricted calf suckling did not reduce the interval to first ovulation, but significantly increased the duration of the posttreatment interovulatory interval, as well as increasing luteal function and size (Rivera et al., 1998; Mackey et al., 2000). Use of a CIDR device for $7 \mathrm{~d}$ and $\mathrm{PGF}_{2 \alpha}$ on $6 \mathrm{~d}$ after insertion, at the start of the breeding period in anestrous suckled beef cows, effectively reduced the interval to first estrus compared with untreated controls ( 8 vs. $11 \mathrm{~d}$ ), but did not influence pregnancy rates over a 31-d breeding period (Table 1; Lucy et al., 2001). In anestrous dairy cows, treatment with CIDR devices for $7 \mathrm{~d}$ following an injection of $\mathrm{PGF}_{2 \alpha}$ at 12 to $14 \mathrm{~d}$ after calving significantly increased the percentage of cows displaying estrus by $30 \mathrm{~d}$ after calving and reduced the interval to first luteal activity, compared with untreated controls (Table 2; Darwash et al., 2001). Thus, 
the use of progesterone alone may be beneficial for initiating normal length estrous cycles and may have a synchrony effect when used with $\mathrm{PGF}_{2 \alpha}$, but the response is variable and does not include synchronization of ovulation.

\section{Use of Progesterone Followed by a Chorionic Gonadotropin}

Treatment with a chorionic gonadotropin after a period of progesterone treatment, with the aim of stimulating ovarian follicular development and production of estradiol, has been evaluated in both suckled and milked cows, although the results obtained have been variable. The development of treatment regimens using a CIDR device with equine chorionic gonadotropin (eCG) injected at the time of device removal was reviewed by Macmillan and Peterson (1993). In a New Zealand study, 8-d treatment with a CIDR device combined with eCG, commencing $10 \mathrm{~d}$ before the start of the breeding period, resulted in a similar response to that observed in cows remaining untreated until $26 \mathrm{~d}$ later (Table 2; Xu et al., 1997a). Similarly, trials conducted in Australian dairy herds, using either CIDR devices or norgestomet implants with eCG, demonstrated no reduction in the mean interval to conception compared with untreated controls (Galloway et al., 1987; Jubb et al., 1989; Table 2). In suckled beef cows, a combination of norgestomet implants and human chorionic gonadotropin at implant removal successfully induced estrous cycles of normal duration in $53 \%$ of cows compared with $0 \%$ of cows that did not receive implants (Table 1; Garcia-Winder et al., 1986). Therefore, eCG may be used following a period of progesterone treat- ment to induce estrus and ovulation in anovulatory anestrous cows, but this protocol does not result in a consistent improvement in reproductive performance. It has largely been replaced by regimens including estradiol.

\section{Use of Progesterone Followed by Estradiol}

Estradiol has been used to stimulate ovulation and expression of estrus following progesterone treatment in a number of studies. In early studies in beef cattle, injections of progesterone for 9 to $14 \mathrm{~d}$ followed by a single injection of estradiol successfully induced estrus and ovulation and reduced the interval to conception, compared with untreated controls (Ulberg and Lindley, 1960; Saiduddin et al., 1968). Use of an oral progestogen followed by an injection of $5 \mathrm{mg}$ of estradiol valerate significantly reduced the interval to first estrus and ovulation; although conception rates to first service were less compared with those of untreated cows (Brown et al., 1972). Later studies using CIDR devices for $7 \mathrm{~d}$ with an injection of $1 \mathrm{mg}$ of estradiol benzoate (EB) given 24 to $30 \mathrm{~h}$ after device removal demonstrated a significant improvement in the percentage of anestrous beef cows displaying estrus and forming corpora lutea with a normal lifespan, as well as conceiving to insemination, compared with treating cows with progesterone alone or no treatment (Table 1; Fike et al., 1997; Lammoglia et al., 1998).

This latter protocol has been extensively evaluated in treating anestrous dairy cattle in New Zealand. Treatment of anovulatory anestrous cows with CIDR devices for $6 \mathrm{~d}$, followed by an injection of $1 \mathrm{mg}$ of EB $24 \mathrm{~h}$ after device removal, typically results in $87 \%$ of

Table 2. Reproductive outcomes from hormonal treatments ( $\mathrm{T}$ ) for anovulatory anestrous dairy cows. Unless otherwise stated controls (C) were untreated.

\begin{tabular}{|c|c|c|c|c|c|}
\hline Reference & Protocol & $\begin{array}{l}\text { No. of cows } \\
(\mathrm{T}, \mathrm{C})\end{array}$ & $\begin{array}{l}\text { Interval }^{1} \\
\text { to first } \\
\text { estrus } \\
\text { (days; T, C) }\end{array}$ & $\begin{array}{l}\text { Pregnancy } \\
\text { rate } \\
(\mathrm{T}, \mathrm{C})\end{array}$ & $\begin{array}{l}\text { Interval }^{1} \\
\text { to conception } \\
\text { (days; } \mathrm{T}, \mathrm{C} \text { ) }\end{array}$ \\
\hline Galloway et al. (1987) & 10-d norgestomet $+\mathrm{PGF}_{2 \alpha}+\mathrm{eCG}$ & 49,46 & \multirow{2}{*}{$14,30^{\mathrm{b}}$} & $47 \%, 20 \%$ by $14 \mathrm{~d}^{3 \mathrm{~b}}$ & 24,31 \\
\hline Hanlon et al. (2000) & 6-d CIDR + EB ${ }^{4}$ & 385,376 & & $60 \%, 39 \%$ by $21 \mathrm{~d}^{3 \mathrm{~b}}$ & $20,27^{\mathrm{b}}$ \\
\hline Jubb et al. (1989) & 7-d CIDR + eCG & 109,95 & 17,19 & & 39,39 \\
\hline $\mathrm{Xu}$ et al. $(2000 \mathrm{~b})$ & $\mathrm{GnRH}+\mathrm{CIDR}+\mathrm{PGF}_{2 \alpha}+\mathrm{EB}$ vs. CIDR $+\mathrm{EB}$ & 602,597 & $9,14^{\mathrm{a}}$ & $44 \%, 26 \%$ by $6 \mathrm{~d}^{3 \mathrm{~b}}$ & 22,26 \\
\hline
\end{tabular}

\footnotetext{
${ }^{a}$ Significance of difference between $\mathrm{T}$ and $\mathrm{C}(P<0.05)$.

${ }^{\mathrm{b}}$ Significance of difference between $\mathrm{T}$ and $\mathrm{C}(P<0.001)$.

${ }^{1}$ Interval from treatment.

${ }^{2} \mathrm{CIDR}=$ controlled internal drug release device.

${ }^{3}$ Days after insemination.

${ }^{4} \mathrm{~EB}=$ estradiol benzoate.
} 
cows being detected in estrus within $7 \mathrm{~d}$ of EB injection (varying from 69 to $100 \%$ among herds) and $42 \%$ of cows conceiving to insemination during this period (varying from 27 to 62\%; Rhodes et al., 1998c). Of the cows detected in estrus, $79 \%$ ovulate following treatment, varying among herds from 54 to $95 \%$ (Rhodes et al., 2001a). Use of this protocol $8 \mathrm{~d}$ before the planned start of the breeding period, compared with $24 \mathrm{~d}$ later, results in a significantly higher percentage of animals being detected in estrus during the first $5 \mathrm{~d}$ of breeding ( $89 \mathrm{vs}$. $31 \%$ ), a higher pregnancy rate by d 21 of the breeding period (60 vs. $39 \%$ ) and a shorter interval to conception (20 vs. 27 d; Hanlon et al., 2000).

A number of variations in this protocol have been evaluated in an attempt to optimize estrous response (submission rates), synchrony of estrus and conception rates. Comparison of $0.75 \mathrm{mg}$ vs. $1.0 \mathrm{mg}$ of EB injected $24 \mathrm{~h}$ after a 6-d period of CIDR device insertion demonstrated similar proportions of animals being detected in estrus within $3 \mathrm{~d}$ of device removal (75\%), but conception rates following insemination tended to be less in cows injected with 0.75 compared with $1.0 \mathrm{mg}$ of EB (Macmillan and Rhodes, 1996). A small trial also examined the effect of injecting $1 \mathrm{mg}$ of EB at the time of CIDR device removal, compared with delaying injection for $18 \mathrm{~h}$. The percentage of animals displaying estrus without ovulating was significantly greater in those injected at $0 \mathrm{~h}$ compared with $18 \mathrm{~h}$ after device removal ( 29 vs. 0\%), although there was no difference between the groups in the percentage of cows that displayed estrus (83\%; M. L. Day, personal communication). It has also been demonstrated that the maturity of the dominant ovarian follicle present at the time of treatment with EB influences ovulation rate and luteal function following ovulation in postpartum suckled cows, with immature follicles having a poorer response than mature follicles (Burke et al., 2001). Thus some delay between the end of progesterone pretreatment and induction of ovulation is required, to allow maturation of the ovulatory follicle.

This treatment protocol has become the standard method for treating cows in New Zealand and Australia that are diagnosed in anovulatory anestrus at the start of the breeding period, with $13 \%$ of the New Zealand dairy herd being treated in the year 2000-2001. The response to treatment is usually good and is considered cost effective, but variation between animals and herds is observed, as discussed later.

\section{Use of Estradiol in Conjunction with Progesterone}

It has been speculated that treatments to induce emergence of a new ovarian follicular wave at the start of progesterone treatment may improve fertility follow- ing insemination at the induced estrus. In cows that have resumed estrous cycles, prolonged periods of treatment with low concentrations of progesterone result in the development of persistent ovarian follicles (Sirois and Fortune, 1990; Savio et al., 1993), that are associated with reduced fertility (Mihm et al., 1994). In these cows, regression of a dominant follicle and synchronous emergence of a new follicle wave may be induced by treatment with GnRH analogues or EB (Roche et al., 1999; Burke et al., 2000). However, in anestrous anovulatory dairy cows, use of EB at the time of CIDR device insertion, either in the form of a 10-mg intravaginal capsule, or an i.m. injection of 0.5 or $1 \mathrm{mg}$ of EB did not significantly influence the percentage of cows displaying estrus or conceiving to first insemination after CIDR device removal (Taufa et al., 1997; Verkerk et al., 1998).

These results reflect the different physiology of anestrous cows and cows that have resumed estrous cycles. Rhodes et al. (2002) demonstrated that anestrous cows treated with small doses of progesterone did not develop persistent ovarian follicles similar to those seen in cows that had initiated estrous cycles before treatment, when monitored using daily transrectal ultrasonography. Concurrent treatment with intravaginal progesterone and an injection of $2 \mathrm{mg}$ of $\mathrm{EB}$ was effective at reducing the duration of dominance of follicles in both groups of cows, but also delayed the emergence of subsequent follicle waves in a proportion of anestrous cows. Similarly, in anovulatory suckled beef cows, treatment with a CIDR device for $8 \mathrm{~d}$, followed by calf removal for 48 $\mathrm{h}$ and injection of $8 \mu \mathrm{g}$ of buserelin, did not change the duration of dominance of the ovulatory follicle compared with no progesterone treatment, but injection of $5 \mathrm{mg}$ of estradiol at the time of device insertion significantly reduced the variation in and mean duration of follicular dominance (Rivera et al., 1998). Another field trial demonstrated that treating anovulatory anestrous dairy cows with $2 \mathrm{mg}$ of $\mathrm{EB}$ at the start of an 8-d period of treatment with a CIDR device, compared with treatment for $6 \mathrm{~d}$ without $\mathrm{EB}$ at the start, improved pregnancy rates by $14 \mathrm{~d}$ after the end of treatment, but did not alter final pregnancy rates (Table 2; McDougall, 2001b). Consequently, when EB is used to synchronize follicle wave emergence in anestrous cows, a longer period of progesterone treatment may be required to allow time for development and maturation of the ovulatory follicle.

\section{Use of GnRH Analogues with Progesterone}

Gonadotropin-releasing hormone analogues may also be used at the start of progesterone treatment to regress the dominant ovarian follicle present and synchronize 
emergence of a new cohort of follicles. This protocol has the additional effect of inducing ovulation and the formation of a corpus luteum in a majority of cows, resulting in elevated concentrations of progesterone in plasma compared with cows not treated with $\mathrm{GnRH}$ (Xu et al., 2000a). To ensure the absence of luteal tissue following progesterone device removal, $\mathrm{PGF}_{2 \alpha}$ is generally included in such protocols. In field trials conducted in pasture-based dairy herds, cows were treated with the GnRH analogue, buserelin, at the start of a 6-, 7or 8-d period of CIDR device insertion, with $\mathrm{PGF}_{2 \alpha}$ at device removal and $1 \mathrm{mg}$ of EB $24 \mathrm{~h}$ later, compared with treatment with a CIDR device and EB alone. Conception rates to first insemination were increased and interval to conception decreased by inclusion of $\mathrm{GnRH}$ in two trials (Xu et al., 2000b; Table 2), but not in a third (Rhodes et al., 2000). In anestrous beef cows treated with GnRH and a norgestomet implant for $7 \mathrm{~d}$ and $\mathrm{PGF}_{2 \alpha}$ injected at implant removal, nearly $60 \%$ of treated cows were detected in estrus within $6 \mathrm{~d}$ after $\mathrm{PGF}_{2 \alpha}$ and pregnancy rates in this period were significantly greater as compared with cows treated with two injections of $\mathrm{PGF}_{2 \alpha}, 14 \mathrm{~d}$ apart (Stevenson et al., 2000). A subsequent study demonstrated that treatment with GnRH followed by $\mathrm{PGF}_{2 \alpha} 7 \mathrm{~d}$ later and GnRH $9 \mathrm{~d}$ later, with a CIDR device inserted for $7 \mathrm{~d}$ after the first $\mathrm{GnRH}$, also improved pregnancy rates in anestrous cows compared with animals treated with $\mathrm{GnRH}, \mathrm{PGF}_{2 \alpha}$ and GnRH (Lamb et al., 2001; Table 1). Thus, treatment regimens including a $\mathrm{GnRH}$ agonist at the commencement of progesterone treatment, and $\mathrm{PGF}_{2 \alpha}$ at the end, produce good responses in anestrous beef and dairy cattle, with results comparable with, or better than, those obtained with other hormonal protocols.

\section{Use of GnRH Analogues with $\mathrm{PGF}_{2 \alpha}$}

The capacity of $\mathrm{GnRH}$ analogues to induce ovulation during the postpartum anovulatory anestrous period, as described above, has been used in programs in combination with $\mathrm{PGF}_{2 \alpha}$ to initiate resumption of estrous cycles, without the requirement for exogenous progesterone treatments. A protocol developed for use in dairy cows that have resumed estrous cycles involves the sequential injection of $\mathrm{GnRH}, \mathrm{PGF}_{2 \alpha}$ and $\mathrm{GnRH}$ at intervals of 7 and 2 or $2.5 \mathrm{~d}$, respectively, with all treated cows being inseminated 16 to $24 \mathrm{~h}$ after the final injection of GnRH, without estrous detection ('Ovsynch' or 'Intercept'; Stevenson et al., 1996; Peters et al., 1999). Use of this protocol, in association with calf isolation, was compared with the use of norgestomet implants and injection of estradiol valerate (Syncro-Mate-B) in anestrous beef cows and cows which had resumed estrous cycles. Pregnancy rates were similar in previously anestrous cows treated with either protocol and were equivalent to those obtained in cows that had resumed estrous cycles before treatment with the Ovsynch protocol (Geary et al., 1998; Table 1). In anestrous pasturebased dairy cows, use of an Ovsynch protocol resulted in similar conception rates to first insemination and in median interval to conception compared with cows treated with CIDR devices and EB and inseminated on detection of estrus (Table 2; McDougall et al., 2001). Another study, conducted in a Florida dairy herd, reported a pregnancy rate of $21 \%$ at $74 \mathrm{~d}$ after insemination in 117 anestrous cows treated with an Ovsynch protocol. Only $50 \%$ of cows ovulated following the first GnRH injection, but pregnancy rates in cows ovulating after both first and second GnRH injections were $40 \%$ at $74 \mathrm{~d}$ and were equivalent to those achieved in cows that had resumed estrous cycles before treatment with a similar protocol (Moreira et al., 2001). In all these studies, the number of cows enrolled was about 100 per treatment group, thus limiting the statistical power of the experiments. However, the results suggest that the Ovsynch protocol may be of benefit in treating anestrous cows in situations where detection of estrus is a problem, although pregnancy rates are lower than those obtained in cows that have resumed estrous cycles (Cartmill et al., 2001). It appears that optimal responses are obtained when a period of elevated progesterone concentrations are achieved after the first injection of GnRH, i.e., when a dominant follicle is present on the ovaries that will ovulate in response to this treatment.

\section{Factors Affecting Response to Hormonal Treatments for Anovulatory Anestrus}

Hormonal treatments can effectively reduce the interval to first ovulation, and synchronize estrus, across cows in a variety of physiological states. However, responses to treatments are not uniform either across herds or across cows within herds and appear to be dependent on those factors influencing the prevalence of anestrus, such as age, body condition, and interval from calving. Younger cows have a lower probability of being detected in estrus after treatment (McDougall, 2001b) and body condition influences pregnancy rates following treatment in both suckled beef and dairy cattle (Humblot et al., 1996; Stevenson et al., 2000; McDougall and Loeffler, unpublished). Mobilization of body fat, as monitored using concentrations of NEFA, was also reported to be higher in suckled beef cows not conceiving compared with those that did conceive following treatment with norgestomet and eCG (Grimard et al., 1997). Interval from calving to treatment is positively associated with the percentage of cows ovulating 
following treatment, as well as pregnancy rate following treatment (Rhodes et al., 1999; Lamb et al., 2001; Rhodes et al., 2001a).

Cows that are in poor body condition or have recently calved may not ovulate following treatment, or may display estrus without ovulating and return to anestrus. The latter group of animals may be assumed to be pregnant, having displayed estrus once and not returned to estrus. At present it is not possible to easily determine which cows have responded and conceived, rather than displayed estrus but not ovulated or conceived, before $30 \mathrm{~d}$ after insemination, when ultrasonographic pregnancy diagnosis can be conducted. In some situations, monitoring milk progesterone concentrations at, say, $14 \mathrm{and} /$ or $21 \mathrm{~d}$ after treatment may be beneficial, especially where 'Cowside' test kits are available.

The concept of depth of anestrus has been used to describe the responsiveness of animals to induction of ovulation (Wright and Malmo, 1992) and factors contributing to the duration of the PPI also influence depth of anestrus. Physiologically, depth of anestrus is related to the frequency of pulsatile LH release; however, there does not appear to be a more readily available measure of depth of anestrus that could be used to predict those animals that will have a poor response to treatments. However, it is clear that animals that have recently calved or have low reserves of body fat are in 'deep' anestrus and are unlikely to resume estrous cycles following hormonal treatment.

\section{HORMONAL TREATMENTS FOR ANESTROUS COWS THAT HAVE OVULATED}

Treatment of cows that have not been detected in estrus, but have a detectable corpus luteum, has mainly focused on the use of $\mathrm{PGF}_{2 \alpha}$. In cows with an ultrasonographically detectable corpus luteum, treatment with $\mathrm{PGF}_{2 \alpha}$ resulted in $55 \%$ of animals being detected in estrus within $6 \mathrm{~d}$ of treatment (Smith et al., 1998). When the corpus luteum was detected following palpation of the ovaries, estrous response rates within $6 \mathrm{~d}$ of treatment averaged $52 \%$ and varied from 36 to $68 \%$, with the majority of cows displaying estrus within $4 \mathrm{~d}$ of treatment (Dailey et al., 1983; Plunkett et al., 1984; Whittier et al., 1989). These results demonstrate that the estrous response to $\mathrm{PGF}_{2 \alpha}$ treatment in this class of cow is not great compared with that observed in cows that have resumed estrous cycles, with between 63 to $88 \%$ of cows being detected in estrous within $7 \mathrm{~d}$ of treatment with $\mathrm{PGF}_{2 \alpha}$ (Xu et al., 1997b). The use of $\mathrm{PGF}_{2 \alpha}$ was compared with an Ovsynch protocol in French dairy cows that had not been detected in estrus but had a palpable corpus luteum. Pregnancy rates by
$50 \mathrm{~d}$ after the start of treatment were similar in the two treatment groups, indicating that the Ovsynch protocol may be used to treat 'subestrous' cows, with the benefit of no requirement for estrous detection (Table 3; Mialot et al., 1999).

Other studies have included progesterone in treatment protocols with the aim of improving pregnancy rates and reducing the interval to conception in this class of cow. Use of a CIDR device for $7 \mathrm{~d}$ with an injection of $2 \mathrm{mg}$ of $\mathrm{EB}$ at device insertion and $\mathrm{PGF}_{2 \alpha}$ at device removal did not improve reproductive performance compared with untreated controls (Table 3; Rhodes et al., 2001b). A subsequent study in which cows were treated with a CIDR device for $8 \mathrm{~d}$ with $2 \mathrm{mg}$ of EB at device insertion and $1 \mathrm{mg}$ of EB $24 \mathrm{~h}$ after device removal demonstrated an increase in the percentage of cows detected in estrus by $7 \mathrm{~d}$ after the start of breeding, from 38 to $85 \%$. Pregnancy rates by $28 \mathrm{~d}$ after the start of the breeding period were also increased and the median interval to conception reduced compared with untreated controls (Table 3; McDougall, 2001b). An alternative protocol, which has also been evaluated in commercial herds, is to treat cows with a GnRH analogue at the time of insertion of a CIDR device, with $\mathrm{PGF}_{2 \alpha}$ at device removal ( $7 \mathrm{~d}$ later), followed by $1 \mathrm{mg}$ of EB 2 $d$ later. This protocol significantly increased submission rates and pregnancy rates in the first $21 \mathrm{~d}$ of breeding compared with untreated cows (Table 3; Rhodes et al., 2000). These results demonstrate that a number of treatment options are available for this class of cow. It appears that a period of progesterone supplementation is beneficial for successful ovulation and insemination, despite the presence of some luteal tissue in the ovaries.

\section{MANAGEMENT TOOLS TO REDUCE THE POSTPARTUM INTERVAL}

\section{Nutritional Strategies}

The main factor influencing duration of the PPI in beef cows and seasonally managed pasture-fed dairy cows is body condition at calving, as previously described in this paper. Attempts to reduce the PPI by manipulating nutrition following calving have proved equivocal. In some studies, improved nutrition postpartum did not significantly reduce the PPI or the percentage of cows ovulating during the breeding season (Wiltbank et al., 1962; Stagg et al., 1998), but in others there was a positive effect (Wright et al., 1987; Stagg et al., 1995; Vizcarra et al., 1998). In pasture-based dairying systems, increased feed allowances after calving were effective in reducing the PPI in the studies of Grainger et al. (1982) and McDougall et al. (1995c); however, supplementation with pasture silage for $30 \mathrm{~d}$ after calving did not affect the percentage of cows ovulating or 
Table 3. Reproductive outcomes from hormonal treatments (T) for anestrous dairy cows with a detectable corpus luteum. Unless otherwise stated, controls (C) were untreated.

\begin{tabular}{|c|c|c|c|c|}
\hline Reference & Protocol & $\begin{array}{l}\text { No. of cows } \\
(\mathrm{T}, \mathrm{C})\end{array}$ & $\begin{array}{l}\text { Pregnancy } \\
\text { rate }(T, C)\end{array}$ & $\begin{array}{l}\text { Interval }^{1} \text { to conception } \\
(\text { days; } \mathrm{T}, \mathrm{C})\end{array}$ \\
\hline McDougall (2001b) & $\mathrm{EB}+8-\mathrm{d} \mathrm{CIDR}+\mathrm{EB}^{2}$ & 84,87 & $56 \%, 43 \%$ by $28 \mathrm{~d}^{3}$ & $21,36^{\mathrm{a}}$ \\
\hline Mialot et al. (1999) & 'Ovsynch' vs. $2 \times \mathrm{PGF}_{2 \alpha}$ & 97,83 & $36 \%, 33 \%$ by $50 \mathrm{~d}^{3}$ & \\
\hline Rhodes et al. (2001b) & $\mathrm{EB}+7-\mathrm{d}$ CIDR $+\mathrm{PGF}_{2 \alpha}$ & 212,226 & $43 \%, 48 \%$ by $21 \mathrm{~d}^{3}$ & 23,24 \\
\hline
\end{tabular}

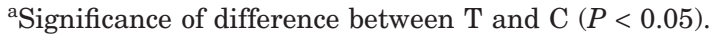

${ }^{1}$ Interval from treatment.

${ }^{2} \mathrm{CIDR}=$ controlled internal drug release device; $\mathrm{EB}$ = estradiol benzoate.

${ }^{3}$ Days after insemination.

detected in estrus before the start of the breeding period (McDougall et al., 1994).

The use of supplemental fats to improve reproductive performance in dairy cows has been reviewed by Staples et al. (1998). The main beneficial effect appears to be on conception rates as a result of changes in follicular and luteal function and may be independent of any effect on energy status of the cow. The effect of fat supplementation on duration of PPI has been evaluated in a few studies. Interval to first ovulation was reduced in Holstein dairy cows fed diets containing $5.2 \%$ fat compared with 3.3 or $7.1 \%$ fat and the development of large ovarian follicles appeared to be increased by this amount of supplementation (Beam and Butler, 1997). In postpartum beef cattle, the percentage of animals displaying luteal activity at the start of the breeding season was also increased by feeding diets supplemented with an extra $3.5 \%$ fat for $30 \mathrm{~d}$ (Wehrman et al., 1991). However, feeding high producing dairy cows with dietary supplements containing calcium salts of long-chain fatty acids did not influence interval to first ovulation and tended to decrease first service conception rates (Lucy et al., 1992). Other studies that have manipulated energy balance during the postpartum period have also failed to significantly influence the duration of the PPI (Spicer et al., 1990; Frajblat et al., 1998).

Feeding a diet that increased circulating insulin concentrations over the first $50 \mathrm{~d}$ of lactation was effective in reducing the PPI in both high and low genetic merit dairy cows without decreasing milk yield (Gong et al., 2002). Another study used daily drenching with propylene glycol for $35 \mathrm{~d}$ in early lactation to increase plasma insulin and glucose concentrations in Holstein cows. This treatment was also effective in reducing the interval to first ovulation after calving without affecting milk production or energy balance (Miyoshi et al., 2001). One of the main factors influencing the effect of nutritional manipulations is the predisposition of individual cows to partition nutrients to milk production rather than body tissues and the ability to increase dietary intake in parallel with increasing milk yield. It has been dem- onstrated that cows with a short PPI produce more milk but also consume more dietary energy compared with cows with an extended PPI (Staples et al., 1990; Lucy et al., 1992).

\section{Other Management Strategies}

In suckled cows, temporary calf removal is effective at reducing the interval to first ovulation. Isolation of calves from their mothers, rather than adjacent penning, further reduces the PPI. Such treatments are usually followed by reduced expression of estrus before ovulation and estrous cycles of short duration unless used in conjunction with progesterone treatment (Rivera et al., 1998; Stagg et al., 1998; Mackey et al., 2000).

Reduction of milking frequency in dairy cows from twice to once daily is practiced by some herd managers in the belief that the decrease in milk production will result in more cows resuming estrous cycles spontaneously. In a controlled study, once daily milking of anovulatory anestrous dairy cows for $28 \mathrm{~d}$, commencing $7 \mathrm{~d}$ before the start of the breeding period, increased the percentage of cows displaying estrus during the first $21 \mathrm{~d}$ of the breeding period by 11 percentage units compared with twice daily milking, but did not influence pregnancy rates or interval to conception. Moreover, milk yield was reduced by $20 \%$ during the period of once daily milking, resulting in significant financial loss (Rhodes et al., 1998a). Another strategy practiced in pasture-based dairy production systems is to graze anestrous cows in a separate herd, with the aim of decreasing competitive grazing pressure on these cows and increasing nutrient intake. However, a controlled trial failed to demonstrate any benefit in terms of reproductive performance from that management practice (Clark et al., 1999).

Exposure of beef suckler cows to teaser bulls or androgen-treated cows during the postpartum period reduced the interval to first estrus in some studies. The effect was dependent on cow condition, with cows in lesser body condition responding in a more positive fashion 
compared with cows in greater body condition (Macmillan et al., 1979; Zalesky et al., 1984; Burns and Spitzer, 1992; Stumpf et al., 1992). However, a small study involving a total of 45 multiparous Holstein cows reported a negative effect of bull exposure on the onset of luteal activity and other reproductive measures (Shipka and Ellis, 1999).

To summarize, a number of management strategies for the postpartum period have been evaluated to examine their effects on reducing PPI and improving reproductive performance. Results obtained are variable and/or not cost effective. Although some nutritional strategies, such as increasing the fat content of diets or manipulating diets to increase circulating concentrations of insulin appear promising, it is not clear whether the results obtained under experimental conditions can be replicated in large-scale field trials. Moreover, responses will be significantly influenced by betweenherd, as well as between-animal, variation. Nevertheless, further research is required to develop these strategies in order to address increasing public concerns regarding the use of hormones in food-producing animals. The most predictable strategy for reducing the PPI in pasture-based dairy or beef cows is to improve body condition at calving, by manipulating energy intakes during the prepartum period.

\section{DISCUSSION}

The requirement to induce early resumption of estrous cycles following calving has been the stimulus for much reproductive research effort over the past 30 to $40 \mathrm{yr}$. This effort was initially focused on the suckled beef cow, due to the seasonal nature of beef farming and the extended PPI resulting from the close maternal bond to the suckling calf (Short et al., 1990). The pasture-based seasonally calving dairy cow displays many similarities to the suckled beef cow. She is required to calve during a narrowly defined seasonal period, often in conditions of nutritional restraint. These cows also have an extended PPI that is strongly dependent on body condition at calving; yet fertility is good once cows have resumed estrous cycles. In contrast, year-round calving, high producing, intensively fed HolsteinFriesian dairy cows traditionally exhibit a short PPI, but expression of estrus and subsequent conception rates are not acceptable (Macmillan et al., 1996). More recently there has been some concern that genetic selection for increased milk yield has led to an increase in the duration of the PPI, in addition to reduced conception rates in these cows (Webb et al., 1999b). However, it has been suggested that increased mean intervals to first ovulation are due to a skewed distribution, re- sulting from a subpopulation of cows with extremely long intervals to first ovulation after calving (Lucy, 2001). Indeed, a study comparing results from two large databases collected from British herds, between 1975 and 1982 and 1995 and 1998, found no change in the proportion of cows with a delayed interval to first ovulation (Royal et al., 2000). There is less urgency for high yielding cows in a year-round calving herd to conceive, compared with cows in a seasonal calving system, but there is still a cost-benefit to be obtained from reducing the interval to conception from 115 to $85 \mathrm{~d}$ after calving and this benefit increases as the interval to conception increases (Esslemont et al., 2001).

This review has focused on the reproductive outcomes of the various strategies available for treating animals with an extended PPI. Although there is undoubted biological advantage in treating anovulatory anestrous cows in many production systems, the economics of such interventions remain to be elucidated. Costs of instituting treatments include drug, labor, veterinary input, and opportunity costs. Potential benefits include shorter inter-calving intervals, reduced culling of nonpregnant cows, and improved labor efficiency related to reduced time spent on estrous detection and calving observations. The economics of reproductive performance is complex as it affects breeding costs, culling, and replacement rates, feed costs, and utilization, as well as milk production. It is further complicated in pasture-based feeding systems where calving spread impacts on feed availability and growth rates. Stochastic simulation modeling has demonstrated that breeding and culling policies, taking into account the productive capacity of cows, have a greater impact on income than improvements in fertility traits alone, such as estrous detection and pregnancy rate (Dijkhuizen et al., 1986; Marsh et al., 1987). The effect of estrous synchronization strategies on calf live weight and interval to conception was modeled in suckled beef cows, demonstrating a beneficial effect of treating anestrous cows, especially in herds with an extended calving spread (Pleasants and Macmillan, 1998). However, economic modeling of specific treatments of anestrus and/or anovulatory cows at herd and cow level has yet to be performed.

The trend of increasing herd size with lower ratios of labor units to number of cows has resulted in changes in management practices and less time available for estrous detection (Lucy, 2001). Additionally, in yearround calving herds the number of cows in estrus at any one time may be fewer than the optimal number required for a sexually active group, thus reducing expression and detection of estrous behavior. The economics of hormonal reproductive interventions are likely to be enhanced where estrous detection rates are poor 


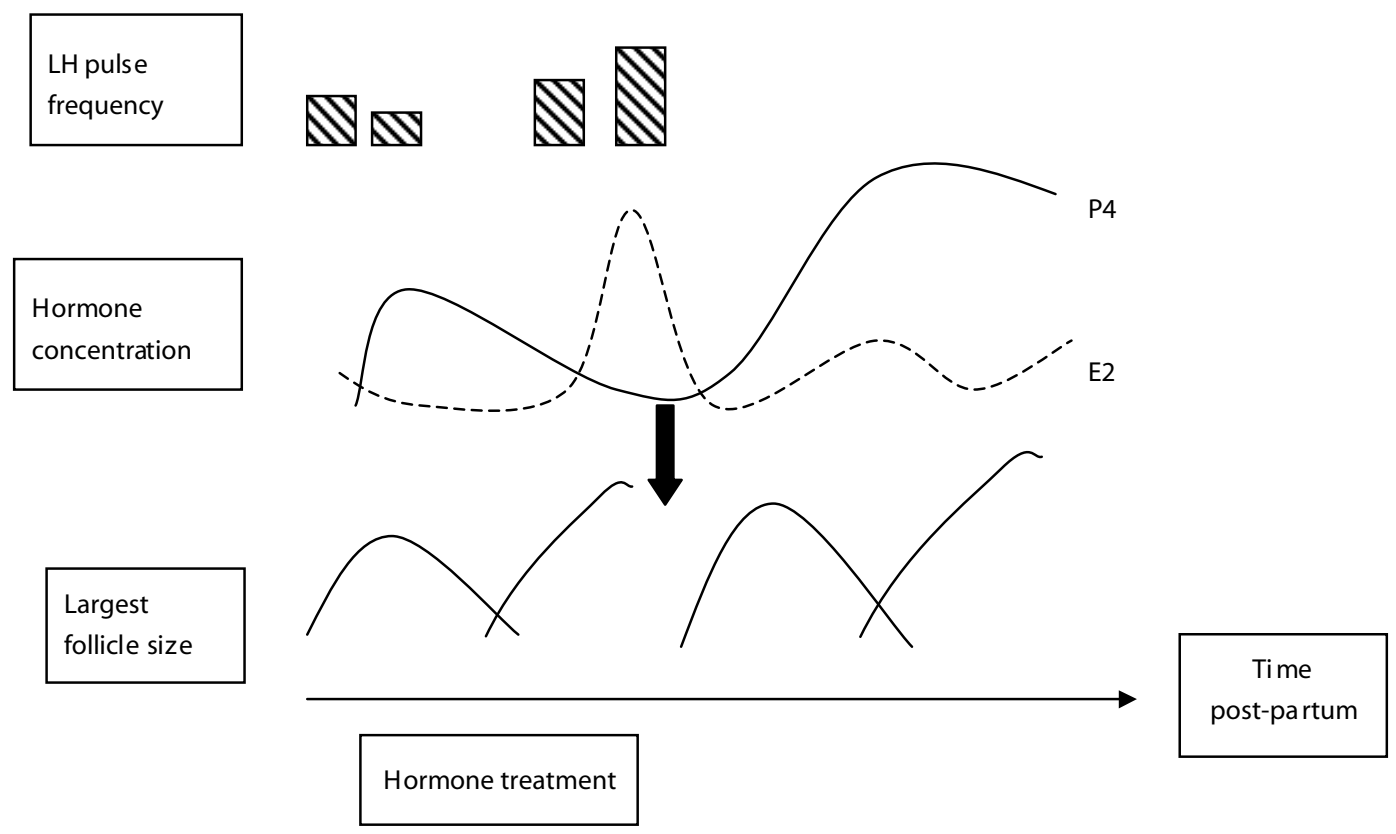

Figure 2. Schematic diagram demonstrating the proposed effect in anovulatory anestrous cows of progesterone treatment, followed by estradiol or $\mathrm{GnRH}$, on the development of largest ovarian follicles and associated changes in circulating concentrations of estradiol (E2), progesterone (P4) and frequency of pulsatile LH release. Ovulation with estrus is indicated by the solid arrow.

especially where fixed time insemination can be used. Some treatments (e.g., Ovsynch) can be used in both anovulatory anestrous cows and cows that have resumed estrous cycles before treatment; although responses are significantly worse in anestrous cows (Cartmill et al., 2001).

Of the various hormonal treatments reviewed, those including progesterone supplementation appear to give the most predictable and reliable results, due to the improvement in the percentage of cows displaying estrus and luteal phases of normal length following treatment and associated increases in conception rates (Tables 1 to 3 ). The proposed effect of treatment with progesterone or a progestogen on hormone concentrations and ovarian follicular development is demonstrated schematically in Figure 2. A transient decrease in pulsatile release of $\mathrm{LH}$ occurs following initial progesterone treatment, but this is followed by an increase in pulse frequency, associated with increasing estradiol synthesis (Garcia-Winder et al., 1986; Nation et al., 2000; Rhodes et al., 2002). Thus the sensitivity of the hypothalamus to the negative feedback effects of estradiol is reduced and, as a result of increased gonadotropic stimulation, the largest ovarian follicle matures and responds to exogenous estradiol or a gonadotropin by ovulating. Moreover, behavioral centers are activated, enabling expression of estrus in a large proportion of animals.
The length of the treatment period with progesterone or a progestogen varies from 6 to $10 \mathrm{~d}$; however, no studies have determined the optimal length of time. In anestrous ewes, a single injection of progesterone in oil given $3 \mathrm{~d}$ before treatment with $\mathrm{GnRH}$ is sufficient to induce ovulation and subsequently normal luteal function (Haresign et al., 1996). The duration of the first period of elevated concentrations of progesterone after parturition averaged $9.6 \mathrm{~d}$ in British dairy cows (Webb et al., 1980), but averaged $6.0 \mathrm{~d}$ in New Zealand pasturefed cows, with $50 \%$ of cows having elevated concentrations for less than $5 \mathrm{~d}$ (McDougall, 1994). It has not been established whether the duration, or the concentration, of progesterone given preceding induction of estrus and ovulation in anestrous cows is the cause of the lower fertility following insemination, compared with cows that have ovulated spontaneously (Xu and Burton, 1997). Some of the between-animal variation in response may be due to differences in feed intakes and/or metabolism influencing circulating concentrations of progesterone (Rabiee et al., 2001). Nevertheless, the present progesterone-based treatment protocols for anovulatory anestrus result in conception rates that are similar to those obtained in cows inseminated following a first spontaneous estrus (Hanlon et al., 2000). In essence, these protocols mimic the first short luteal phase (Figures 1 and 2) and response to treatment depends on the depth of anestrus at the time of 
treatment, as discussed above. Hormonal treatments cannot accelerate the recovery process in every animal to induce a fertile condition equivalent to that following spontaneous resumption of estrous cycles. Thus, it is likely that the physiological status of the cow immediately before treatment contributes to her lesser fertility, rather than the treatment used to induce resumption of estrous cycles.

A combination of management changes and hormonal treatment may result in higher conception rates. It has been reported that a short period of improved nutrition before synchronization of estrus, or induction of ovulation, improves fertility following insemination in suckled beef cows in poor body condition (Khireddine et al., 1998). It is not known whether a similar effect would be observed in dairy cattle, in which dietary supplementation may be partitioned towards increased milk production (McDougall et al., 1994); however, targeted use of specific supplements around the time of breeding and in cows diagnosed anestrus or at risk of being anestrus, would be worth investigating.

Results obtained from some of the studies conducted in New Zealand commercial herds have demonstrated that the mean or median interval to conception following treatment of anestrous anovulatory cows are similar to those obtained in cows that have resumed estrous cycles (Xu and Burton, 1997; Day et al., 2000). In three herds, the reproductive performance of anovulatory anestrous cows treated with CIDR devices and EB was compared with that of cows that had resumed estrous cycles spontaneously. Conception rates to first insemination were significantly lower in treated anestrous cows (40 vs. $57 \%$ ), but the percentage of cows inseminated during the first $4 \mathrm{~d}$ of breeding was greater (93 vs. $26 \%$ ), resulting in similar pregnancy rates after 28 $\mathrm{d}$ of breeding (72 vs. $66 \%$ ) and similar mean intervals to conception ( 22 vs. 23 d; Day et al., 2000). Figure 3 shows the pattern of conception in these herds during the first $80 \mathrm{~d}$ of the breeding period for treated anestrus cows compared with cows that had resumed estrous cycles spontaneously. These results indicate that in herds with good estrous detection rates, the calving pattern of anestrous anovulatory cows treated with a progesterone-based protocol can be comparable to that of cows that have initiated estrous cycles.

Hormonal treatments do not address the underlying causes of a prolonged PPI. In order to reduce this inter$\mathrm{val}$ in the long term, management changes will need to be made. Improving body condition at calving appears to be the most predictable strategy for reducing the PPI in pasture-based cattle, but in practice herd-owners may be constrained by feed availability during late pregnancy and the long-term benefits of feeding cows to maintain good body condition have not been evalu- ated in economic terms. Moreover, the direct effects of nutritional supplementation on reproductive performance are not clear, because dairy cows, especially high yielding Holstein Friesians, will tend to partition extra nutrients towards milk production rather than reproduction. While there is a continuing emphasis on managing and selecting cows for production rather than reproduction, it is unlikely that the fertility of the modern dairy cow will improve. It has been suggested that continued genetic selection for milk yield has resulted in a reduction in reproductive performance, although whether this includes a lengthening PPI is debatable (Lucy, 2001). It is clear that negative genetic correlations between yield and fertility exist and in the long term it will be necessary to include some measure of fertility as a breeding goal in addition to simply yield. The effect of including fertility traits in selection indexes for breeding programs was discussed by Pryce and Veerkamp (2001) and many European countries already produce genetic evaluations for fertility. This review has illustrated that a number of effective hormonal treatment protocols exist for reducing the PPI in both milked and suckled cattle; however, the challenge is now to address the more difficult problem of how these protocols can be combined with changes in management practices to optimize outcomes. To understand the complex interrelationships of genetics, production and reproduction, it is likely that sophisticated cow and herd level modeling will be required.

\section{CONCLUSIONS}

Cows exhibiting a prolonged interval from calving to first ovulation are characterized by a delay in the

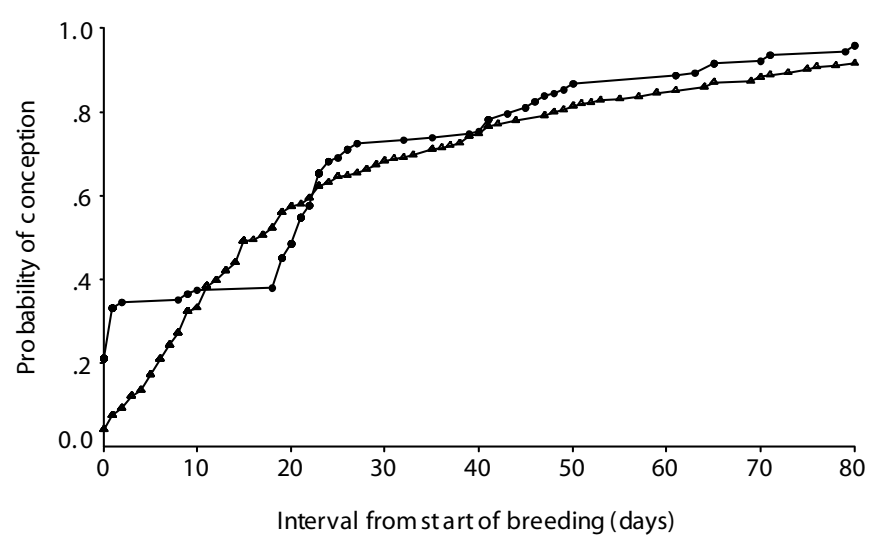

Figure 3. Probability of conception during the first $80 \mathrm{~d}$ of the breeding period for anovulatory anestrous dairy cows treated with progesterone and estradiol benzoate $(\mathrm{n}=142,0)$ and untreated cows which had resumed estrous cycles before the start of the breeding period $(n=214, \Delta)$, in three New Zealand herds (data from M.L Day, personal communication). 
increase of pulsatile release of $\mathrm{LH}$, lower circulating concentrations of estradiol and some metabolic hormones such as insulin or IGF-I. Although ovarian follicular growth and turnover is observed, maturation and ovulation of dominant follicles does not take place. The main factors delaying the increase in LH pulse frequency are suckling, lower energy intake, inadequate body reserves, increased partitioning of energy to milk production, and peripartum disease.

Treatment options for cows with a prolonged PPI include management changes and hormonal treatments. Hormonal treatments have the advantage over management changes in producing a synchronized estrous response, thus facilitating the use of artificial insemination. Where a period of progesterone treatment is included in the protocol, the percentage of cows displaying estrus within a given period is usually greater and the subsequent luteal phase is of normal duration. Protocols that aim to synchronize the time of ovulation (e.g., Ovsynch) can also be used without the requirement for estrous detection, although conception rates to a timed insemination tend to be less compared with those following insemination at an observed estrus.

Trying to manipulate body condition, dietary intakes, or dietary composition during the postpartum period in either suckled or milked cows has resulted in variable effects on duration of the PPI. In suckled beef cows, temporary calf removal can be used to induce ovulation, but again, the use of a progestogen or progesterone improves expression of estrus and significantly increases the proportion of cows developing a corpus luteum of normal life span. The most predictable management strategy for reducing the PPI in cows on pasturebased systems is to improve body condition during the prepartum period.

The reproductive performance of anestrous cows following some hormonal treatments can be equivalent to that of cows that have resumed estrous cycles, in herds with greater estrous detection rates. However, the response to any treatment appears to be dependent on those factors that influence 'depth' of anestrus (i.e., body condition, age, and interval from calving). To improve the response to hormonal treatments it is necessary to address those factors that induce a prolonged PPI.

\section{ACKNOWLEDGMENTS}

The authors thank J. Kinder and P. Jolly for helpful suggestions made during preparation of this manuscript.

\section{REFERENCES}

Beam, S. W., and W. R. Butler. 1997. Energy balance and ovarian follicle development prior to the first ovulation postpartum in dairy cows receiving three levels of dietary fat. Biol. Reprod. 56:133-142

Beam, S. W., and W. R. Butler. 1999. Effects of energy balance on follicular development and first ovulation in postpartum dairy cows. J. Reprod. Fertil. Suppl. 54:411-424.

Brown, J. G., D. W. Peterson, and W. D. Foote. 1972. Reproductive response of beef cows to exogenous progestogen, estrogen and gonadotropins at various stages postpartum. J. Anim. Sci. 35:362-369.

Burke, C. R., S. McDougall, and K. L. Macmillan. 1995. Effects of breed and calving liveweight on postpartum ovarian activity in pasture-fed dairy heifers. Proc. N.Z. Soc. Anim. Prod. 55:76-78.

Burke, C. R., M. L. Day, C. R. Bunt, and K. L. Macmillan. 2000. Use of a small dose of estradiol benzoate during diestrus to synchronize development of the ovulatory follicle in cattle. J. Anim. Sci. 78:145-151.

Burke, C. R., M. L. Mussard, D. E. Grum, and M. L. Day. 2001. Effects of maturity of the potential ovulatory follicle on induction of oestrus and ovulation in cattle with oestradiol benzoate. Anim. Reprod. Sci. 66:161-174.

Burns, P. D., and J. C. Spitzer. 1992. Influence of biostimulation on reproduction in postpartum beef cows. J. Anim. Sci. 70:358-362.

Butler, W. R., R. W. Everett, and C. E. Coppock. 1981. The relationships between energy balance, milk production and ovulation in postpartum Holstein cows. J. Anim. Sci. 53:742-748.

Canfield, R. W., and W. R. Butler. 1990. Energy balance and pulsatile LH secretion in early postpartum dairy cattle. Domest. Anim. Endocrinol. 7:323-330.

Cartmill, J. A., S. Z. El-Zarkouny, B. A. Hensley, G. C. Lamb, and J. S. Stevenson. 2001. Stage of cycle, incidence, and timing of ovulation, and pregnancy rates in dairy cattle after three timed breeding protocols. J. Dairy Sci. 84:1051-1059.

Clark, B. A., F. M. Rhodes, and S. McDougall. 1999. Separate grazing does not shorten the postpartum anoestrous interval in anoestrous cows. Proc. N.Z. Soc. Anim. Prod. 59:55-57.

Cooper, D. A., D. A. Carver, P. Villeneuvu, W. J. Silvia, and E. K. Inskeep. 1991. Effects of progestogen treatment on concentrations of prostaglandins and oxytocin in plasma from the posterior vena cava of post-partum beef cows. J. Reprod. Fertil. 91:411-421.

Copelin, J. P., M. F. Smith, H. A. Garverick, and R. S. Youngquist. 1987. Effect of the uterus on subnormal luteal function in anoestrous beef cows. J. Anim. Sci. 64:1506-1511.

Crowe, M. A., D. Goulding, A. Baguisi, M. P. Boland, and J. F. Roche. 1993. Induced ovulation of the first postpartum dominant follicle in beef suckler cows using a GnRH analogue. J. Reprod. Fertil. 99:551-555.

Crowe, M. A., V. Padmanabhan, M. Mihm, I. Z. Beitins, and J. F. Roche. 1998. Resumption of follicular waves in beef cows is not associated with periparturient changes in follicle-stimulating hormone heterogeneity despite major changes in steroid and luteinizing hormone concentrations. Biol. Reprod. 58:1445-1450.

Dailey, R. A., E. K. Inskeep, S. P. Washburn, and J. C. Price. 1983. Use of prostaglandin $\mathrm{F}_{2 \alpha}$ or gonadotropin releasing hormone in treating problem breeding cows. J. Dairy Sci. 66:1721-1727.

Darwash, A. O., G. E. Lamming, and J. A. Woolliams. 1997a. Estimation of genetic variation in the interval from calving to postpartum ovulation of dairy cows. J. Dairy Sci. 80:1227-1234.

Darwash, A. O., G. E. Lamming, and J. A. Woolliams. 1997b. The phenotypic association between the interval to post-partum ovulation and traditional measures of fertility in dairy cattle. Anim. Sci. 65:9-16.

Darwash, A. O., G. E. Lamming, and M. D. Royal. 2001. A protocol for initiating oestrus and ovulation early post partum in dairy cows. Anim. Sci. 72:539-546.

Day, M. L., and L. H. Anderson. 1998. Current concepts on the control of puberty in cattle. J. Anim. Sci. 76(Suppl. 3):76:1-15.

Day, M. L., C. R. Burke, V. K. Taufa, A. M. Day, and K. L. Macmillan. 2000. The strategic use of estradiol to enhance fertility and submission rates of progestin-based estrus synchronization programs in dairy herds. J. Anim. Sci. 78:523-529. 
de Vries, M. J., and R. F. Veerkamp. 2000. Energy balance of dairy cattle in relation to milk production variables and fertility. J. Dairy Sci. 83:62-69.

Dijkhuizen, A. A., J. Stelwagen, and J. A. Renkema. 1986. A stochastic model for the simulation of management decision in dairy herds, with special reference to production, reproduction, culling and income. Prev. Vet. Med. 4:273-289.

Ducker, M. J., R. A. Haggett, W. J. Fisher, and S. V. Morant. 1985. Nutrition and reproductive performance of dairy cattle 1 . The effect of level of feeding in late pregnancy and around the time of insemination on the reproductive performance of first lactation dairy heifers. Anim. Prod. 41:1-12.

Esslemont, R. J., M. A. Kossaibati, and J. Allcock. 2001. Economics of fertility in dairy cows. Pages 19-29 in Fertility in the High Producing Dairy Cow. Occ. Pub. 26. M. G. Diskin, ed. British Society of Animal Science, Edinburgh.

Fike, K. E., M. L. Day, E. K. Inskeep, J. E. Kinder, R. E. Short, and H. D. Hafs. 1997. Estrus and luteal function in suckled beef cows that were anestrous when treated with an intravaginal device containing progesterone with or without a subsequent injection of estradiol benzoate. J. Anim. Sci. 75:2009-2015.

Fonseca, F. A., J. H. Britt, B. T. McDaniel, J. C. Wilk, and A. H. Rakes. 1983. Reproductive traits of Holsteins and Jerseys. Effects of age, milk yield, and clinical abnormalities on involution of cervix and uterus, ovulation, estrous cycles, detection of estrus, conception rate, and days open. J. Dairy Sci. 66:1128-1147.

Frajblat, M., S. W. Beam, and W. R. Butler. 1998. Plasma leptin concentrations and first postpartum ovulation in dairy cows differing in energy balance. J. Anim. Sci. (Suppl. 1):76:231. (Abstr.)

Galloway, D. B., P. Brightling, J. Malmo, G. A. Anderson, M. T. Larcombe, and P. J. Wright. 1987. A clinical trial using a regimen which includes a norgestomet implant and norgestomet plus oestradiol valerate injection as a treatment for anoestrus in dairy cows. Aust. Vet. J. 64:187-189.

Garcia-Winder, M., K. Imakawa, M. L. Day, D. D. Zalesky, R. J. Kittok, and J. E. Kinder. 1984. Effect of suckling and ovariectomy on the control of luteinizing hormone secretion during the postpartum period in beef cows. Biol. Reprod. 31:771-778.

Garcia-Winder, M., P. E. Lewis, D. R. Deaver, V. G. Smith, G. S. Lewis, and E. K. Inskeep. 1986. Endocrine profiles associated with life span of induced corpora lutea in postpartum beef cows. J. Anim. Sci. 62:1353-1362.

Garcia-Winder, M., P. E. Lewis, E. C. Townsend, and E. K. Inskeep. 1987. Effects of norgestomet on follicular development in postpartum beef cows. J. Anim. Sci. 64:1099-1109.

Geary, T. W., J. C. Whittier, E. R. Downing, D. G. LeFever, R. W. Silcox, M. D. Holland, T. M. Nett, and G. D. Niswender. 1998. Pregnancy rates of postpartum beef cows that were synchronized using Syncro-Mate-B or the Ovsynch protocol. J. Anim. Sci. 76:1523-1527.

Gong, J. G., W. J. Lee, P. C. Garnsworthy, and R. Webb. 2002. Effect of dietary induced increases in circulating insulin concentrations during the early postpartum period on reproductive function in dairy cows. Reproduction 123:419-427.

Grainger, C., G. D. Wilhelms, and A. A. McGowan. 1982. Effect of body condition at calving and level of feeding in early lactation on milk production of dairy cows. Aust. J. Exp. Agric. Husb. 22:9-17.

Grimard, B., P. Humblot, J. P. Mialot, N. Jeanguyot, D. Sauvant, and M. Thibier. 1997. Absence of response to oestrus induction and synchronization treatment is related to lipid mobilization in suckled beef cows. Reprod. Nutr. Dev. 37:129-140.

Gutierrez, C. G., J. G. Gong, T. A. Bramley, and T. Weatherly. 1999. Effects of genetic selection for milk yield on metabolic hormones and follicular development in postpartum dairy cattle. J. Reprod. Fertil. Abstr. Ser. 24:32. (Abstr.)

Hanlon, D. W., J. J. Wichtel, Z. Z. Xu, and L. J. Burton. 2000. The reproductive performance of anoestrous dairy cows following treatment with progesterone and oestradiol prior to the start of mating. N.Z. Vet. J. 48:136-143.
Haresign, W., G. F. Basiouni, and M. Khalid. 1996. Effect of progesterone priming on gonadotropin secretion and luteal function in GnRH-treated seasonally anoestrous ewes. Anim. Sci. 62:97-103.

Henricks, D. M., J. F. Dickey, J. R. Hill, and W. E. Johnston. 1972. Plasma estrogen and progesterone levels after mating, and during late pregnancy and postpartum in cows. Endocrinology 90:1336-1342.

Humblot, P., B. Grimard, O. Ribon, B. Khireddine, V. Dervishi, and M. Thibier. 1996. Sources of variation of post-partum cyclicity, ovulation and pregnancy rates in primiparous Charolais cows treated with norgestomet implants and PMSG. Theriogenology 46:1085-1096.

Inskeep, E. K., T. D. Braden, P. E. Lewis, M. Garcia-Winder, and G. D. Niswender. 1988. Receptors for luteinizing hormone and follicle-stimulating hormone in largest follicles of postpartum beef cows. Biol. Reprod. 38:587-591.

Jolly, P. D., S. McDougall, L. A. Fitzpatrick, K. L. Macmillan, and K. W. Entwistle. 1995. Physiological effects of undernutrition on postpartum anoestrus in cows. J. Reprod. Fertil. Suppl. 49:477-492.

Jonsson, N. N., M. R. McGowan, K. McGuigan, T. M. Davison, A. M. Hussain, M. Kafi, and A. Matschoss. 1997. Relationship among calving season, heat load, energy balance and postpartum ovulation of dairy cows in a subtropical environment. Anim. Reprod. Sci. 47:315-326.

Jubb, T. F., P. Brightling, J. Malmo, M. T. Larcombe, G. A. Anderson, and S. J. Hides. 1989. Evaluation of a regimen using a progesterone releasing intravaginal device (CIDR) and PMSG as a treatment for post partum anoestrus in dairy cattle. Aust. Vet. J. 66:334-336.

Khireddine, B., B. Griard, A. A. Ponter, C. Ponsart, H. Boudjenah, J. P. Mialot, D. Sauvant, and P. Humblot. 1998. Influence of flushing on LH secretion, follicular growth and the response to estrous synchronization treatment in suckled beef cows. Theriogenology 49:1409-1423.

Kyle, S. D., C. J. Callahan, and R. D. Allrich. 1992. Effect of progesterone on the expression of estrus at the first postpartum ovulation in dairy cattle. J. Dairy Sci. 75:1456-1460.

Lamb, G. C., J. S. Stevenson, D. J. Kesler, H. A. Garverick, D. R. Brown, and B. E. Salfen. 2001. Inclusion of an intravaginal progesterone insert plus $\mathrm{GnRH}$ and prostaglandin $\mathrm{F}_{2 \alpha}$ for ovulation control in postpartum suckled beef cows. J. Anim. Sci. 79:2253-2259.

Lamming, G. E., and A. O. Darwash. 1998. The use of milk progesterone profiles to characterise components of subfertility in milked dairy cows. Anim. Reprod. Sci. 52:175-190.

Lamming, G. E., D. C. Wathes, and A. R. Peters. 1981. Endocrine patterns of the post-partum cow. J. Reprod. Fertil. Suppl. 30:155-170.

Lammoglia, M. A., R. E. Short, S. E. Bellows, R. A. Bellows, M. D. MacNeil, and H. D. Hafs. 1998. Induced and synchronized estrus in cattle: Dose titration of estradiol benzoate in peripubertal heifers and postpartum cows after treatment with an intravaginal progesterone-releasing insert and prostaglandin $\mathrm{F}_{2 \alpha}$. J. Anim. Sci. 76:1662-1670.

Lucy, M. C. 2001. Reproductive loss in high-producing dairy cattle: Where will it end? J. Dairy Sci. 84:1277-1293.

Lucy, M. C., C. R. Staples, W. W. Thatcher, P. S. Erickson, R. M. Cleale, J. L. Firkins, J. H. Clark, M. R. Murphy, and B. O. Brodie. 1992. Influence of diet composition, dry-matter intake, milk production and energy balance on time of postpartum ovulation and fertility in dairy cows. Anim. Prod. 54:323-331.

Lucy, M. C., C. R. Bilby, C. J. Kirby, W. Yuan, and C. K. Boyd. 1999. Role of growth hormone in development and maintenance of follicles and corpora lutea. J. Reprod. Fertil. Suppl. 54:49-59.

Lucy, M. C., H. J. Billings, W. R. Butler, L. R. Ehnis, M. J. Fields, D. J. Kesler, J. E. Kinder, R. C. Mattos, R. E. Short, W. W. Thatcher, R. P. Wettemann, J. V. Yelich, and H. D. Hafs. 2001. Efficacy of an intravaginal progesterone insert and an injection of $\mathrm{PGF}_{2 \alpha}$ for synchronizing estrus and shortening the interval to pregnancy in postpartum beef cows, peripubertal beef heifers, and dairy heifers. J. Anim. Sci. 79:982-995. 
Mackey, D. R., J. M. Sreenan, J. F. Roche, and M. G. Diskin. 2000. The effect of progesterone alone or in combination with estradiol on follicular dynamics, gonadotropin profiles, and estrus in beef cows following calf isolation and restricted suckling. J. Anim. Sci. 78:1917-1929.

Macmillan, K. L. 1983. Post-partum interval to oestrus in monozygous twin cows and possible effects of maternal bonding. N.Z. J. Agric. Res. 26:451-454.

Macmillan, K. L. 2002. Advances in bovine theriogenology in New Zealand. 1. Pregnancy, parturition and the postpartum period. N.Z. Vet. J. 50 (Suppl.):67-73.

Macmillan, K. L., and D. G. Clayton. 1980. Factors influencing the interval to post-partum oestrus, conception date and empty rate in an intensively managed dairy herd. Proc. N.Z. Soc. Anim. Prod. 40:236-239.

Macmillan, K. L., and A. J. Peterson. 1993. A new intravaginal progesterone releasing device for cattle (CIDR-B) for oestrous synchronization, increasing pregnancy rates and the treatment of postpartum anoestrus. Anim. Reprod. Sci. 33:1-25.

Macmillan, K. L., and F. M. Rhodes. 1996. Synchrony systems for dairy heifers and cows. Proc. Soc. Dairy Cattle Vet. N.Z. Vet. Assoc. 13:149-158.

Macmillan, K. L., A. J. Allison, and G. A. Struthers. 1979. Some effects of running bulls with suckling cows or heifers during the premating period. N.Z. J. Exp. Agric. 7:121-124.

Macmillan, K. L., I. J. Lean, and C. T. Westwood. 1996. The effects of lactation on the fertility of dairy cows. Aust. Vet. J. 73:141-147.

Mann, G. E., and G. E. Lamming. 2000. The role of sub-optimal preovulatory oestradiol secretion in the aetiology of premature luteolysis during the short oestrous cycle in the cow. Anim. Reprod. Sci. 64:171-180.

Marsh, W. E., A. A. Dijkhuizen, and R. S. Morris. 1987. An economic comparison of four culling decision rules for reproductive failure in United States dairy herds using DairyORACLE. J. Dairy Sci. 70:1274-1280.

McDougall, S. 1994. Postpartum anoestrum in the pasture grazed New Zealand dairy cow. Ph.D. Thesis. Massey University, Palmerston North, New Zealand.

McDougall, S. 2001a. Effects of periparturient diseases and conditions on the reproductive performance of New Zealand dairy cows. N.Z. Vet. J. 49:60-67.

McDougall, S. 2001b. Reproductive performance of anovulatory anoestrous postpartum dairy cows following treatment with two progesterone and oestradiol benzoate-based protocols, with or without resynchrony. N.Z. Vet. J. 49:187-194.

McDougall, S., and F. M. Rhodes. 1999. Detection of a corpus luteum in apparently anoestrous cows by manual palpation, transrectal ultrasonography and plasma progesterone concentration. N.Z. Vet. J. 47:47-52.

McDougall, S., C. R. Burke, K. L. Macmillan, and N. B. Williamson. 1992. The effect of pretreatment with progesterone on the oestrous response to oestradiol- $17 \beta$ benzoate in the postpartum dairy cow. Proc. N.Z. Soc. Anim. Prod. 52:157-160.

McDougall, S., P. Leijnse, A. M. Day, K. L. Macmillan, and N. B. Williamson. 1993. A case control study of anoestrum in New Zealand dairy cows. Proc. N.Z. Soc. Anim. Prod. 53:101-103.

McDougall, S., D. A. Clark, K. L. Macmillan, and N. B. Williamson. 1994. Some effects of feeding pasture silage as a supplement to pasture on reproductive performance in lactating dairy cows. Proc. N.Z. Soc. Anim. Prod. 54:95-98.

McDougall, S., C. R. Burke, K. L. Macmillan, and N. B. Williamson. 1995a. Patterns of follicular development during periods of anovulation in pasture-fed dairy cows after calving. Res. Vet. Sci. 58:212-216.

McDougall, S., N. B. Williamson, and K. L. Macmillan. 1995b. GnRH induces ovulation of a dominant follicle in primiparous dairy cows undergoing anovulatory follicle turnover. Anim. Reprod. Sci. 39:205-214.

McDougall, S., C. R. Burke, N. B. Williamson, and K. L. Macmillan. 1995c. The effect of stocking rate and breed on the period of postpartum anoestrum in grazing dairy cattle. Proc. N.Z. Soc. Anim. Prod. 55:236-238.
McDougall, S., K. L. Macmillan, and N. B. Williamson. 1998. Factors associated with a prolonged period of postpartum anoestrum in pasture-fed dairy cattle. Proc. World Assoc. Buiatrics 20:657-662.

McDougall, S., A. A. Cullum, F. M. Anniss, and F. M. Rhodes. 2001. Treatment of anovulatory anoestrous postpartum dairy cows with a gonadotrophin-releasing hormone $(\mathrm{GnRH})$, prostaglandin $\mathrm{F}_{2 \alpha}$, GnRH regimen or with progesterone and oestradiol benzoate. N.Z. Vet. J. 49:168-172.

Mialot, J. P., G. Laummonnier, C. Ponsart, H. Fauxpoint, E. Barassin, A. A. Ponter, and F. Deletang. 1999. Postpartum subestrus in dairy cows: Comparison of treatment with prostaglandin $\mathrm{F}_{2 \alpha}$ or GnRH + prostaglandin $\mathrm{F}_{2 \alpha}+\mathrm{GnRH}$. Theriogenology 52:901-911.

Mihm, M., A. Baguisi, M. P. Boland, and J. F. Roche. 1994. Association between the duration of dominance of the ovulatory follicle and pregnancy rate in beef heifers. J. Reprod. Fertil. 102:123-130.

Miksch, E. D., D. G. LeFever, G. Mukembo, J. C. Spitzer, and J. N. Wiltbank. 1978. Synchronization of estrus in beef cattle II. Effect of an injection of norgestomet and an estrogen in conjunction with a norgestomet implant in heifers and cows. Theriogenology 10:201-210.

Miyoshi, S., J. L. Pate, and D. L. Palmquist. 2001. Effects of propylene glycol drenching on energy balance, plasma glucose, plasma insulin, ovarian function and conception in dairy cows. Anim. Reprod. Sci. 68:29-43.

Montgomery, G. W., I. C. Scott, and N. L. Hudson. 1985. An interaction between season of calving and nutrition on the resumption of ovarian cycles in post-partum beef cattle. J. Reprod. Fertil. 73:45-50.

Moreira, F., C. Orlandi, C. A. Risco, R. Mattos, F. L. Lopes, and W. W. Thatcher. 2001. Effects of presynchronization and bovine somatotropin on pregnancy rates to a timed artificial insemination protocol in lactating dairy cows. J. Dairy Sci. 84:1646-1659.

Murphy, M. G., M. P. Boland, and J. F. Roche. 1990. Pattern of follicular growth and resumption of ovarian activity in postpartum beef suckler cows. J. Reprod. Fertil. 90:523-533.

Nation, D. P., C. R. Burke, G. Parton, R. Stevenson, and K. L. Macmillan. 2000. Hormonal and ovarian responses to a 5-day progesterone treatment in anoestrous dairy cows in the third week postpartum. Anim. Reprod. Sci. 63:13-25.

Opsomer, G., Y. T. Grohn, J. Hertl, M. Coryn, H. Deluyker, and A. de Kruif. 2000a. Risk factors for postpartum ovarian dysfunction in high producing dairy cows in Belgium: A field study. Theriogenology 53:841-857.

Opsomer, G., H. Laevens, N. Steegen, and A. de Kruif. 2000b. A descriptive study of postpartum anoestrus in nine high-yielding dairy herds in Flanders. Vlaams Diergeneeskundig Tijdschrift 69:31-37.

Peters, A. R., S. J. Ward, M. J. Warren, P. J. Gordon, G. E. Mann, and R. Webb. 1999. Ovarian and hormonal responses of cows to treatment with an analogue of gonadotrophin releasing hormone and prostaglandin $\mathrm{F}_{2 \alpha}$. Vet. Rec. 144:343-346.

Pleasants, A. B., and K. L. Macmillan. 1998. An evaluation of the use of synchrony technology in beef breeding herds. Anim. Sci. 67:269-276.

Plunkett, S. S., J. S. Stevenson, and E. P. Call. 1984. Prostaglandin $\mathrm{F}_{2 \alpha}$ for lactating dairy cows with a palpable corpus luteum but unobserved estrus. J. Dairy Sci. 67:380-387.

Pryce, J. E., and R. F. Veerkamp. 2001. The incorporation of fertility indices in genetic improvement programmes. Pages 237-249 in Fertility in the high producing dairy cow. Occ. Pub. M. G. Diskin, ed. British Society of Animal Science, Edinburgh.

Rabiee, A. R., K. L. Macmillan, and F. Schwarzenberger. 2001. The effect of level of feed intake on progesterone clearance rate by measuring faecal progesterone metabolites in grazing dairy cows. Anim. Reprod. Sci. 67:205-214.

Ramirez-Godinez, J. A., G. H. Kiracofe, R. R. Schalles, and G. D. Niswender. 1982. Endocrine patterns in the postpartum beef cow associated with weaning: A comparison of the short and subsequent normal cycles. J. Anim. Sci. 55:153-158.

Rhodes, F. M., L. A. Fitzpatrick, K. W. Entwistle, and G. De'ath. 1995. Sequential changes in ovarian follicular dynamics in Bos 
indicus heifers before and after nutritional anoestrus. J. Reprod. Fertil. 104:41-49.

Rhodes, F. M., B. A. Clark, K. L. Macmillan, and S. McDougall. 1998a. Use of once daily milking or treatment with progesterone and oestradiol benzoate in anoestrous cows. Proc. N.Z. Soc. Anim. Prod. 58:44-46.

Rhodes, F. M., B. A. Clark, D. P. Nation, V. K. Taufa, M. L. Day, A. M. Day, K. L. Macmillan, and S. McDougall. 1998b. Factors influencing the prevalence of postpartum anoestrus in New Zealand dairy cows. Proc. N.Z. Soc. Anim. Prod. 58:79-81.

Rhodes, F. M., B. A. Clark, D. P. Nation, V. K. Taufa, M. L. Day, A. M. Day, K. L. Macmillan, and S. McDougall. 1998c. Treatment of postpartum anoestrus in New Zealand dairy cows with progesterone and oestradiol benzoate. Proc. World Assoc. Buiatrics 20:607-611.

Rhodes, F. M., B. A. Clark, S. McDougall, and K. L. Macmillan. 1999. Insemination at the second of two induced oestrous periods in anoestrous dairy cows increases conception rates to first service. N.Z. Vet. J. 47:39-43.

Rhodes, F. M., S. McDougall, G. A. Verkerk, Z. Z. Xu, and A. Cullum. 2000. Treatment of the non-cycling cow. Proc. Soc. of Dairy Cattle Vets of the N.Z. Vet. Assoc. 17:125-134.

Rhodes, F. M., S. McDougall, S. R. Morgan, and G. A. Verkerk. 2001a. Supplementing treated anoestrous dairy cows with progesterone does not increase conception rates. N.Z. Vet. J. 49:8-12.

Rhodes, F. M., S. McDougall, and G. A. Verkerk. 2001b. Reproductive performance of dairy cows not detected in oestrus but with a detectable corpus luteum, in response to treatment with progesterone, oestradiol benzoate and prostaglandin $\mathrm{F}_{2 \alpha}$. N.Z. Vet. J. 49:13-17.

Rhodes, F. M., C. R. Burke, B. A. Clark, M. L. Day, and K. L. Macmillan. 2002. Effect of treatment with progesterone and oestradiol benzoate on ovarian follicular turnover in postpartum anoestrous cows and cows which have resumed oestrous cycles. Anim. Reprod. Sci. 69:139-150.

Rivera, G. M., C. G. Goni, M. A. Chavas, S. B. Ferrero, and G. A. Bo. 1998. Ovarian follicular wave synchronization and induction of ovulation in postpartum beef cows. Theriogenology 49:1365-1375.

Roberts, A. J., R. A. I. Nugent, J. Klindt, and T. G. Jenkins. 1997. Circulating insulin-like growth factor I, insulin-like growth factor binding proteins, growth hormone, and resumption of estrus in postpartum cows subjected to dietary energy restriction. J. Anim. Sci. 75:1909-1917.

Roche, J. F., E. J. Austin, M. Ryan, M. O'Rourke, M. Mihm, and M. G. Diskin. 1999. Regulation of follicle waves to maximize fertility in cattle. J. Reprod. Fertil. Suppl. 54:61-71.

Royal, M. D., A. O. Darwash, A. P. F. Flint, R. Webb, J. A. Woolliams, and G. E. Lamming. 2000. Declining fertility in dairy cattle: Changes in traditional and endocrine parameters of fertility. Anim. Sci. 70:487-501.

Saiduddin, S., M. M. Quevedo, and W. D. Foote. 1968. Response of beef cows to exogenous progesterone hormone and estradiol at various stages postpartum. J. Anim. Sci. 27:1015-1020.

Savio, J. D., M. P. Boland, N. Hynes, and J. F. Roche. 1990. Resumption of follicular activity in the early postpartum period of dairy cows. J. Reprod. Fertil. 88:569-579.

Savio, J. D., W. W. Thatcher, L. Badinga, R. L. de la Sota, and D. Wolfenson. 1993. Regulation of dominant follicle turnover during the oestrous cycle in cows. J. Reprod. Fertil. 97:197-203.

Senatore, E. M., W. R. Butler, and P. A. Oltenacu. 1996. Relationship between energy balance and post-partum ovarian activity and fertility in first lactation dairy cows. Anim. Sci. 62:17-23.

Shipka, M. P., and L. C. Ellis. 1999. Effects of bull exposure on postpartum ovarian activity of dairy cows. Anim. Reprod. Sci. 54:237-244.

Short, R. E., R. A. Bellows, R. B. Staigmiller, J. G. Berardinelli, and E. E. Custer. 1990. Physiological mechanisms controlling anestrus and infertility in postpartum beef cattle. J. Anim. Sci. 68:799-816.

Sirois, J., and J. E. Fortune. 1990. Lengthening the bovine estrous cycle with low levels of exogenous progesterone: A model for studying ovarian follicular dominance. Endocrinology 127:916-925.
Smith, S. T., W. R. Ward, and H. Dobson. 1998. Use of ultrasonography to help to predict observed oestrus in dairy cows after the administration of prostaglandin $\mathrm{F}_{2 \alpha}$. Vet. Rec. 142:271-274.

Spicer, L. J., W. B. Tucker, and G. D. Adams. 1990. Insulin-like growth factor-1 in dairy cows: Relationships among energy balance, body condition, ovarian activity and estrous behaviour. J. Dairy Sci. 73:929-937.

Stagg, K., M. G. Diskin, J. M. Sreenan, and J. F. Roche. 1995. Follicular development in long-term anoestrous suckler beef cows fed two levels of energy postpartum. Anim. Reprod. Sci. 38:49-61.

Stagg, K., L. J. Spicer, J. M. Sreenan, J. F. Roche, and M. G. Diskin. 1998. Effect of calf isolation on follicular wave dynamics, gonadotropin and metabolic hormone changes, and to interval to first ovulation in beef cows fed either of two energy levels postpartum. Biol. Reprod. 59:777-783.

Staples, C. R., W. W. Thatcher, and J. H. Clark. 1990. Relationship between ovarian activity and energy status during the early postpartum period of high producing dairy cows. J. Dairy Sci. 73:938-947.

Staples, C. R., J. M. Burke, and W. W. Thatcher. 1998. Influence of supplemental fats on reproductive tissues and performance of lactating cows. J. Dairy Sci. 81:856-871.

Stevenson, J. S., and E. P. Call. 1983. Influence of early estrus, ovulation, and insemination on fertility in postpartum Holstein cows. Theriogenology 19:367-375.

Stevenson, J. S., Y. Kobayashi, M. P. Shipka, and K. C. Rauchholz. 1996. Altering conception of dairy cattle by gonadotropin-releasing hormone preceding luteolysis induced by prostaglandin $\mathrm{F}_{2 \alpha}$. J. Dairy Sci. 79:402-410.

Stevenson, J. S., K. E. Thompson, W. L. Forbes, G. C. Lamb, D. M. Grieger, and L. R. Corah. 2000. Synchronizing estrus and (or) ovulation in beef cows after combinations of $\mathrm{GnRH}$, norgestomet, and prostaglandin $\mathrm{F}_{2 \alpha}$ with or without timed insemination. J. Anim. Sci. 78:1747-1758.

Stockdale, C. R. 2001. Body condition at calving and the performance of dairy cows in early lactation under Australian conditions: A review. Aust. J. Exp. Agric. 41:823-839.

Stumpf, T. T., M. W. Wolfe, P. L. Wolfe, M. L. Day, R. J. Kittok, and J. E. Kinder. 1992. Weight changes prepartum and presence of bulls post-partum interact to affect duration of postpartum anoestrus in cows. J. Anim. Sci. 70:3133-3137.

Taufa, V. K., K. L. Macmillan, D. P. Nation, A. M. Day, and M. J. Ashcroft. 1997. The responses of lactating dairy cows treated for anoestrum to an oestradiol capsule and an oestradiol injection. Proc. N.Z. Soc. Anim. Prod. 57:241.

Thatcher, W. W., and C. J. Wilcox. 1973. Postpartum estrus as an indicator of reproductive status in the dairy cow. J. Dairy Sci. $56: 608-610$.

Ulberg, L. C., and C. E. Lindley. 1960. Use of progesterone and estrogen in the control of reproductive activities in beef cattle. $\mathrm{J}$. Anim. Sci. 19:1132-1142.

Verkerk, G. A., V. K. Taufa, S. R. Morgan, B. A. Clark, and K. L. Macmillan. 1998. Effects of oestradiol benzoate by injection at CIDR insertion for the treatment of postpartum anovulatory anoestrus in dairy cows. Proc. N.Z. Soc. Anim. Prod. 58:82-84.

Villa-Godoy, A., T. L. Hughes, R. S. Emery, L. T. Chapin, and R. L. Fogwell. 1988. Association between energy balance and luteal function in lactating dairy cows. J. Dairy Sci. 71:1063-1072.

Vizcarra, J. A., R. P. Wettemann, J. C. Spitzer, and D. G. Morrison. 1998. Body condition at parturition and postpartum weight gain influence luteal activity and concentrations of glucose, insulin, and non-esterified fatty acids in plasma of primiparous beef cows. J. Anim. Sci. 76:927-936.

Webb, R., G. E. Lamming, N. B. Haynes, and G. R. Foxcroft. 1980. Plasma progesterone and gonadotrophin concentrations and ovarian activity in post-partum dairy cows. J. Reprod. Fertil. 59:133-143.

Webb, R., B. K. Campbell, H. A. Garverick, J. G. Gong, C. G. Gutierrez, and D. G. Armstrong. 1999a. Molecular mechanisms regulating follicular recruitment and selection. J. Reprod. Fertil. Suppl. 54:33-48. 
Webb, R., P. C. Garnsworthy, J. G. Gong, R. S. Robinson, and D. C. Wathes. 1999b. Consequences for reproductive function of metabolic adaptation to load. Pages 99-112 in Metabolic Stress in Dairy Cows. Occ. Pub. 24. C. M. Oldham, G. Simm, A. F. Groen, B. L. Nielsen, J. E. Pryce, and T. L. J. Lawrence, ed. British Society of Animal Science, Edinburgh.

Wehrman, M. E., T. H. J. Welsh, and G. L. Williams. 1991. Dietinduced hyperlipidemia in cattle modifies the intrafollicular cholesterol environment, modulates ovarian follicular dynamics, and hastens the onset of postpartum luteal activity. Biol. Reprod. 45:514-522.

Whittier, W. D., F. C. Gwazdauskas, and M. L. McGilliard. 1989. Prostaglandin $\mathrm{F}_{2 \alpha}$ usage in a dairy reproduction program for treatment of unobserved estrus, pyometra and ovarian luteal cysts. Theriogenology 32:693-704.

Williams, G. L., and M. K. Griffith. 1995. Sensory and behavioural control of gonadotrophin secretion during suckling-mediated anovulation in cows. J. Reprod. Fertil. Suppl. 49:463-475.

Wiltbank, J. N., N. W. Rowden, J. E. Ingalls, K. E. Gregory, and R. M. Koch. 1962. Effect of energy level on reproductive phenomena of mature Hereford cows. J. Anim. Sci. 21:219.

Wiltbank, M. C., A. Gumen, and R. Sartori. 2002. Physiological classification of anovulatory conditions in cattle. Theriogenology 57:21-52.

Wright, I. A., S. M. Rhind, A. J. F. Russel, T. K. Whyte, A. J. McBean, and S. R. McMillen. 1987. Effects of body condition, food intake and temporary calf separation on the duration of the postpartum anoestrous period and associated LH, FSH and prolactin concentrations in beef cows. Anim. Prod. 45:395-402.

Wright, P. J., and J. Malmo. 1992. Pharmacologic manipulation of fertility. Veterinary Clinics of North America: Food Animal Practice 8(1):57-89.
Xu, Z. Z., and L. J. Burton. 1997. Reproductive performance of postpartum anoestrous dairy cows treated with progesterone and oestradiol benzoate. N.Z. Vet. J. 45:213-214.

Xu, Z. Z., L. J. Burton, and K. L. Macmillan. 1997a. Treatment of postpartum anoestrous dairy cows with progesterone, oestradiol and equine chorionic gonadotrophin. N.Z. Vet. J. 45:205-207.

Xu, Z. Z., L. J. Burton, and K. L. Macmillan. 1997b. Reproductive performance of lactating dairy cows following estrus synchronization regimens with $\mathrm{PGF}_{2 \alpha}$ and progesterone. Theriogenology 47:687-701.

Xu, Z. Z., G. A. Verkerk, J. F. Mee, S. R. Morgan, B. A. Clark, C. R. Burke, and L. J. Burton. 2000a. Progesterone and follicular changes in postpartum noncyclic dairy cows after treatment with progesterone and estradiol or with progesterone, $\mathrm{GnRH}, \mathrm{PGF}_{20}$ and estradiol. Theriogenology 54:273-282.

Xu, Z. Z., L. J. Burton, S. McDougall, and P. D. Jolly. 2000b. Treatment of noncyclic lactating dairy cows with progesterone and estradiol or with progesterone, $\mathrm{GnRH}$, prostaglandin $\mathrm{F}_{2 \alpha}$ and estradiol. J. Dairy Sci. 83:464-470.

Zalesky, D. D., M. L. Day, M. Garcia-Winder, K. Imakawa, R. J. Kittok, M. J. D'Occhio, and J. E. Kinder. 1984. Influence of exposure to bulls on resumption of estrous cycles following parturition in beef cows. J. Anim. Sci. 59:1135-1139.

Zollers, W. G. J., H. A. Garverick, and M. F. Smith. 1989. Oxytocininduced release of prostaglandin $\mathrm{F}_{2 \alpha}$ in postpartum beef cows: Comparison of short versus normal luteal phases. Biol. Reprod. $41: 262-267$

Zollers, W. G. J., H. A. Garverick, M. F. Smith, R. J. Moffatt, B. E. Salfen, and R. S. Youngquist. 1993. Concentration of progesterone and oxytocin receptors in endometrium of postpartum cows expected to have a short or normal oestrus cycle. J. Reprod. Fertil. 97:329-337.

Zurek, E., G. R. Foxcroft, and J. J. Kennelly. 1995. Metabolic status and interval to first ovulation in postpartum dairy cows. J. Dairy Sci. 78:1909-1920. 